\title{
1 Restoring tropical forest composition is more difficult, but 2 recovering tree-cover is faster, when neighbouring forests 3 are young
}

4

5 Toledo, R.M 1,2. (ORCID iD 0000-0002-0152-2797),

6 Perring, M.P 2,3(ORCID iD 0000-0001-8553-4893),

7 Verheyen, $\mathrm{K}^{2}$. (ORCID iD 0000-0002-2067-9108),

8 Martini A. M. Z.4,

9 Ferreira, M. P 5 ,

10 Santos, R. F ${ }^{1}$ (ORCID iD 0000-0002-1171-6659)

$12{ }^{1}$ LEPaC, Departamento de Ecologia, Instituto, de Biociências, Universidade de São Paulo, São Paulo, 13 SP, Brasil

${ }^{2}$ Forest \& Nature Lab, Department of Environment, Ghent University, Geraardsbergsesteenweg 267, 9090 Melle-Gontrode, Belgium

${ }^{3}$ School of Biological Sciences, The University of Western Australia, 35 Stirling Highway, Crawley,

19 WA 6009, Australia

$20{ }^{4}$ LabTrop, Departamento de Ecologia, Instituto, de Biociências, Universidade de São Paulo, São

21 Paulo, SP, Brasil

225 Universidade de São Paulo, Escola Superior de Agricultura Luiz de Queiroz, Departamento de 23 Ciências Biológicas, Piracicaba, SP, Brazil

\section{ABStract}

\section{Context}

28 Neighbouring forests constitute biological sources that enable the succession from species-poor

29 systems, such as tree-plantings, to highly diverse forests. However, old remnants are becoming rare

30 in tropical agricultural landscapes. 
32 We were interested in if, and how, spontaneous regeneration under tree-plantings reflects the age

33 and the amount of the neighbouring forest cover. We anticipated that older forests promote a

34 compositionally broader recovery in neighbouring tree-plantings, because older forests likely

35 include disturbance-sensitive species, particularly within least deforested landscapes.

\section{Methods}

37 We studied twenty-seven restoration sites implemented as tree-plantings in the Brazilian Atlantic

38 Forest. We quantified the effects of age and amount of neighbouring forest cover on structural and

39 compositional characteristics of the regeneration community $(\mathrm{dbh}<5 \mathrm{~cm})$. We used two landscape

40 groups (presence, or absence, of forests older than 30yrs.) with a similar areal range of forest cover,

41 enabling the disentanglement of forest age from forest amount effects on regeneration community

42 responses.

\section{Results}

44 Surprisingly, we found that greater forest cover correlated with denser and more species-rich

45 regeneration communities only when neighbouring forests were young. This pattern was promoted

46 by non-vertebrate dispersed species. Besides, regeneration communities in tree-plantings near to

47 young forests had lower seed-mass and relative abundances of forest-specialists, compared to

48 communities found near old forest patches.

\section{Conclusion}

50 Regeneration is likely denser in landscapes of vast young-forest coverage. However, small-seeded

51 and habitat-generalist species, frequently related to disturbance tolerance, tend to be dominant if

52 old-growth forests are far away. This biased seed source appears to preclude the restoration of

53 typical historic tropical forest composition.

\section{KEYWORDS}

55 Atlantic Forest, Brazil, forest restoration, landscape history, regeneration, secondary succession

\section{INTRODUCTION}

57 During the last century, unprecedented extensive conversion of naturally forested areas to

58 agricultural and urban areas spread throughout the tropics (Chazdon, 2014). Since 2005,

59 deforested areas cover most of the domains of tropical moist forests (Asner et al. 2009). Such

60 drastic change in landscape composition increased risks of biodiversity loss and decline of 
ecosystem services, reinforcing the urgent need for forest-protective policies and restoration

62 programs (Kueffer and Bunbury, 2014; Suding et al. 2015). Correspondingly, large forest-

63 restoration initiatives have included Brazilian deforested regions (Chazdon 2008; Durigan et al.

64 2013; Holl 2017). Forest restoration aims to lever secondary succession in degraded areas by

65 employing approaches that may range from removal of anthropogenic disturbance to the intensive manipulation of species composition and abiotic conditions (Meli et al. 2017).

Active forest restoration is particularly recommended in severely deforested landscapes (Malhi et al. 2014), and typically involves native tree-plantings (Lamb et al. 2005; Rodrigues et al. 2009) because agricultural practices that are commonly adopted in crop-fields and pasture lands tend to eliminate tropical forest species from the seed bank (Lopez-Toledo and Martinez-Ramos, 2011). These planted native trees are then expected to shelter regeneration communities, which comprise 72 young descendants of planted trees together with individuals of the same and other species 73 dispersed from neighbouring communities (Brancalion et al. 2010; Bertachi et al. 2015; Reid et al. 74 2015). Planted trees increase seed arrivals by attracting seed dispersing animals, as recognized by 75 the "applied nucleation" concept (i.e. triggering restoration with small vegetation patches as focal areas for recovery; Zahawi et al. (2013)). Likewise, Catterall (2018) endorses attracted fauna as a restoration driver, rather than a passenger; although some animals can be much slower in occupying revegetated areas, such as the specialists of mature-growth habitats.

Arriving propagules play a crucial role in tropical forest recovery because planting a substantial fraction of the original diversity is unfeasible (Lamb et al. 2005). Accordingly, the role of nearby forest patches as biodiversity repositories has been recognised as a key asset for tropical forest restoration (Banks-Leite et al. 2014; Chazdon and Guariguata 2016; Crouzeilles and Curran, 2016; Molin et al. 2017). Essentially, forest restoration must take advantage from the biodiversity of natural habitats that is shared with surrounding anthropogenic habitat. Then, such functional connectivity may promote the local planted diversity to increasingly reflect the regional diversity (Ricklefs, 1987; Shackelford et al. 2017). In this context, the relevance of landscape forest-cover has been highlighted, because the arrival of diversity in restoration sites can be intensified or attenuated by landscape structure (Tscharntke et al. 2012). models addressing forest restoration as the single operational proxy for functional connectivity

91 between natural habitats and habitats under recovery (e.g. Brancalion et al. 2019, Rozendaal et al. 
2019, and Strassburg et al. 2019). Typically, the amount of forest cover is calculated with remotely

93 sensed tree-cover (Hansen et al. 2013). However, this remote sensing approach does not consider

94 the quality of the forest cover e.g. age, species composition. Recent second-growth and old forests

95 have been computed together as "forested areas".

96 At present, regenerating forests are the predominant form of forest cover in the tropics (Chazdon,

97 2014), as typically observed within the Brazilian Atlantic Forest domain (e.g. Lira et al. 2012; Ferraz

98 et al. 2014). Second growth is vital for the recovery of degraded landscapes (Chazdon and

99 Guariguata, 2016) and is rapidly expanding in the tropics, as a consequence of agricultural

100 abandonment in terrains of lower farming capabilities (Asner et al. 2009). However, Gibson et al.

101 (2016) have shown that regenerating forests are limited in taking on the role of old-growth forests

102 since they present substantially lower biodiversity. These findings raise the question to what extent

103 young secondary forest can replace old-growth forest patches in assisting forest restoration.

104 Scarcity of neighbouring mature forests implies a compositional limitation to forest recovery (Holl

105 2007; Middendorp et al. 2016). Some species groups tend to be particularly sensitive to heavy

106 deforestation or degradation. For instance, the arrival of vertebrate-dispersed and large-seeded

107 plants is more dependent on neighbouring old-growth forests (Lamb et al. 2005; Costa et al. 2012).

108 A lack of large-seeded species in the seed rain of tree plantings can be persistent (Reid et al 2015),

109 although de la Peña-Domene (2016) have shown that large-seeded trees from pre-existing forest

110 patches can mitigate such constraints by enhancing the recolonization of adjacent sites. Moreover,

111 younger forests have fewer reproductive trees of late-successional, forest-specialist species

112 (Liebsch et al. 2008). The trend of increased rarity of these disturbance-sensitive species where

113 neighbouring forests are young may be increased by heavy defaunation (Galetti et al. 2017) and by

114 greater contribution from opportunistic non-forest trees in the seed rain (Zahawi et al. 2013).

115 Here, we evaluated the effect of amount and age of nearby forests on the regeneration community

116 that we observe during tropical forest restoration. We anticipated that regeneration communities

117 growing underneath tree-plantings would present compositional limitations not only in highly

118 deforested landscapes, but also in landscapes where mature forests are absent and neighbouring

119 forest cover comprises young, second growth, forests. This compositional limitation would consist

120 of reduced species richness, and a community composition dominated by generalist plant species

121 rather than forest specialists, and lacking large-seeded and/or vertebrate dispersed species. We

122 compared regeneration communities underneath tree-plantings from two groups, separated 
123 according to the age of neighbouring forest cover: neighbouring forest cover encompasses old

124 forest patches; neighbouring forest cover is solely made up of young forest patches. The range of

125 variation in the amount of neighbouring forest cover was similar for both age groups: young and

126 old forest cover. We tested if larger and older forest cover promotes regeneration communities in

127 restoration sites that are denser, more species-rich, and have an increased presence of vertebrate-

128 dispersed, large seeded and forest-specialist species. Improved predictions on the effect of

129 landscape composition will likely assist forest restoration planning in tropical agricultural

130 landscapes by supporting the selection of more effective approaches.

\section{Methods}

\section{$132 \quad 3.1$ STUDY AREA}

133 The restoration program "Projeto de Recuperação de Matas Ciliares" (PRMC), coordinated by the

134 Environmental Agency from São Paulo State, was launched in 2005 and established a milestone for

135 Brazilian forest restoration policies. This unprecedented initiative included the implementation of

136 over 500 demonstration sites distributed across the São Paulo state, which were set in private lands

137 by regional working groups (Wuethrich, 2007; Chazdon, 2008). The present study was undertaken

138 in the six Eastern watersheds covered by PRMC, comprising a 150-Km-wide region (Online

139 Resource 1 for study region map). All restoration sites we surveyed are located within the

140 boundaries of the Atlantic-plateau geomorphological and botanical provinces (Scudeller et al. 2001)

141 and the Serra do Mar coastal forests ecoregion (Olson et al. 2001). The agricultural expansion in

142 this region of São Paulo state occurred in the nineteenth century promoting widespread and abrupt

143 deforestation: deforest lands were used by agriculture and natural areas were degraded (Dean,

144 1991). Currently, the land-use mosaic is vastly dominated by pastures, which typically enclose

145 pockets of croplands, urban patches, commercial tree plantations, and tropical-forest of varied

146 successional stages.

147 Sampling design

148 We conducted a vegetation survey and neighbouring forest cover assessment, having selected a

149 group of 27 restoration sites, according to the protocol outlined below, from the 133 demonstration

150 sites located within six watersheds. These watersheds are highly variable in area and number of

151 restoration sites, which resulted in an uneven distribution of surveyed sites among watersheds

152 (Fig. 1). Firstly, our screening process selected restoration projects that were implemented on 
153 former pasturelands with the following protocol: seedlings of over sixty species were planted in a

154 regular density of 1,667 seedlings/ha. Unfortunately, the list of planted species is taxonomically

155 inaccurate due to the use of common names in the records so we are unsure about the exact planted 156 composition at each site. However, it is likely that a similar composition was planted at each site,

157 and we assume this in our interpretation of our results. Secondly, we excluded sites that did not 158 present any forest cover in a 200-m-wide buffer during the restoration implementation, as well as 159 sites that presented values outside 1.5 times the interquartile range for: area (i.e. $<0.2$ ha and $>2.2$ 160 ha), altitude (i.e. $<596 \mathrm{~m}$ and $>1508 \mathrm{~m}$ ), annual precipitation (i.e. $<1370 \mathrm{~mm}$ and $>1735 \mathrm{~mm}$ ) and 161 slope (i.e. >31\%). Lastly, we set a minimum distance of $1 \mathrm{~km}$ between selected sites by discarding 162 the most dissimilar neighbouring sites (again, on area, altitude, annual precipitation, and slope). To 163 do so, we used the database from PRMC combined with climate models and the digital elevation 164 model provided by WorldClim (Hijmans, 2005). The spatial structure of our sampling is presented 165 in Figure 1, and the location map is presented in Online Resource 1.

166 Fig. 1.Spatial structure of our sampling design. Spatial distribution of watersheds in our study region; 167 restoration sites in a watershed; and vegetation-plots in a restoration site. The 200-m-buffer is shown 168 for the vegetation plot 'I.m.3' overlaying the raster resulted from the NDVI time series.

\subsection{Data collection}

171 Vegetation data

172 Vegetation survey was conducted within tree plantations seven years after planting. We randomly

173 located four coordinates within each restoration site to indicate the centre of each $200-\mathrm{m}^{2}$ -

174 vegetation plot. Measured by the central coordinate, the average distance between vegetation plots 175 from the same restoration site was 53.6 meters. Then, inside each plot, a $100-\mathrm{m}^{2}$-subplot was 176 positioned with the same central point. Within the large plots, we quantified and identified all trees 177 with diameter at breast height $(\mathrm{dbh}) \geq 5 \mathrm{~cm}$. In the subplot, we quantified and identified all woody 178 individual taller than $0.5 \mathrm{~m}$, with $\mathrm{dbh}<5 \mathrm{~cm}$. For multi-stemmed trees, the inclusion criterion was a 179 combined basal area at breast height larger than $19.6 \mathrm{~cm}^{2}$ i.e. an equivalent diameter of $5 \mathrm{~cm}$. The 180 cut-off dbh of $5 \mathrm{~cm}$ was set after exploratory field observations, in which we noted that 181 systematically displayed individuals (clearly the planted ones) often presented $\mathrm{dbh}>10 \mathrm{~cm}$, and 182 rarely $<7 \mathrm{~cm}$. Thus, for our analysis, we assumed individuals of species of $\geq 5 \mathrm{~cm}$ dbh represented 183 adults, and individuals of $<5 \mathrm{~cm}$ dbh represented juveniles of the regeneration community i.e. our 
focal response. As well as the regularity of spacing of the planted individuals of $\geq 5 \mathrm{~cm} \mathrm{dbh}$, they

185 were also observed to be flowering/fruiting, in a manner not observed for those individuals of $186<5 \mathrm{~cm}$ dbh. Given this, and the fact that seed banks of woody species are typically short lived in agricultural land, we are confident that we have accurately captured a description of the regeneration community, and that any variation in this community is driven by differing seed arrival and survival under a tree plantings. Individuals that could not be consistently identified in the field had samples taken to allow further identification at the ESA Herbarium (Department of Biology, ESALQ-USP). The nomenclature followed the database "Flora of Brazil 2020," according to the APG IV system (Chase et al. 2016).

Botanical databases were used to classify the identified species according to the seed-dispersal

194 syndrome (by vertebrates or by non-vertebrates), seed mass (grams per seed) and habitat

195 selectivity (moist-forest-specialist or habitat-generalists). We compiled information on seed-

196 dispersal syndrome and seed mass from literature (references and species list presented in Online

197 Resource 2). To classify species according to habitat selectivity, we first assessed the species

198 geographical distribution through the Global Biodiversity Information Facility (GBIF;

199 http://www.gbif.org accessed March 2017). We then compared each occurrence map to the 200 terrestrial ecoregions map (Olson et al. 2001): species solely found within broadleaf tropical moist201 forests domains were considered as "forest-specialists", while "generalist-species" presented a 202 broader distribution that overlapped with moist-forest habitats but also included records from 203 non-forest natural habitats such as tropical savannas and shrublands (Toledo et al. 2018a).

\section{Remote sensing data: Landscape predictor variables}

205 Forest patches were mapped within a 200 m-buffer-zones around each vegetation plot; this 206 distance is consistent with findings from Souza et al. (2014), Rezende et al. (2015) and Toledo et al. 207 (2018a), which found substantial neighbourhood effects on forest patches in regenerating forests in 208 distances up to 200 meters. In addition, considering Tambosi et al (2014), the probability of several 209 Atlantic Forest species dispersing across non-forested areas is likely halved by 50m, and reduced 210 by $75 \%$ across a distance of $100 \mathrm{~m}$. Maps indicating the distribution of native forest were produced 211 with the visual interpretation of colour orthophotos, with spatial resolution of 1 meter, which were 212 taken two years before the plantings. The natural forests have their boundaries vectorized at a 213 scale of 1:4.000 with the software ArcGis 10.1. We assumed we had correctly delineated forest 214 cover based on the photos: mapping activities did not include field validation i.e. ground-truthing. 
215 The history i.e. the age class of these 'two-years-before-planting' forest patch areas was assessed by

216 Normalized Difference Vegetation Index (NDVI) (Rouse, 1973) using a time series of Landsat-5

217 images (spatial resolution of nearly 30m) from the dry seasons of 1985, 2000 and 2014. We

218 classified as "young forests" forest patches with low NDVI measured in images from 1985 and/or

219 2000. Patches with persistent high NDVI values (i.e. > 0.3) were considered as "old forests", even if

220 they have expanded along the time series and became partially covered by younger second growth.

221 The percentage of forest cover was then calculated with data from 2014, resulting in the values of

222 "forest cover" we tested as a predictor in our models.

223 The selection of 30 years as the cut-off considered models from Liebsch et al. (2008) and Poorter et

224 al. (2016), which indicate that, from the 4th decade of forest recovery, increases in structural and

225 compositional similarity to mature forest are likely to be minor. Finally, all plots were classified into

226 two classes, according to the presence or absence of old forest in the surrounding buffer. This

227 procedure resulted in the binary categorical predictor used in our models: young forest cover

228 (young-FC, hereafter), and old forest cover (old-FC, hereafter). The young-FC group comprised 40

229 plots from 10 restoration sites, with an average forest cover of 15.6\%, ranging up to $49.9 \%$.

230 Similarly, the old-FC group comprised 68 plots from 17 restoration sites, with an average forest

231 cover of $18.4 \%$, ranging up to $41.6 \%$. The average "young forest gain" in the old-FC group (i.e. forest

232 expansion during the past 30 yrs.) was 32.8\%, ranging at plot level from $0 \%$ to $84.5 \%$ (data shown

233 for each restoration site in the Online Resource 3).

\subsection{DATA ANALYSIS}

235 Data analysis was performed with R.3.6.0. (R Foundation for Statistical Computing, Vienna, AT).

236 Considering that vegetation plots were nested by watershed and restoration sites, linear mixed

237 modelling (with nlme package version 3.1-139, R-Core Team) was used to assess the effects of age

238 and amount of neighbouring forest-cover on six indicators of structural and compositional

239 restoration of regeneration communities ( $\mathrm{DBH}<5 \mathrm{~cm})$. The response variables analysed in the

240 models were: a- stem density, b- observed species richness, c- stem density of vertebrate-dispersed

241 species, d-stem density of non-vertebrate-dispersed species, e- community-weighted mean for

242 seed mass (CWM-SM) and f-relative abundance of moist-forest specialists; as measured at the plot

243 level. We tested watershed, restoration site, and both watershed and restoration site as random

244 factors in each model. We found that only considering the restoration sites provided the best

245 combination on goodness of fit and model simplicity. Goodness-of-fit between models were 
compared with marginal and conditional R² (see Nakagawa et al. 2017) with MuMIn package version 1.43.6.

248 The effect of three predictors was assessed in these six models: percentage of forest cover in the

$249200 \mathrm{~m}$-wide buffer, presence or absence of old (> 30 year old) fragments, and a third predictor,

250 which is the analogous measure of the response variable, but obtained from the respective adult 251 community $(\mathrm{DBH} \geq 5 \mathrm{~cm})$ (e.g. 'adult' stem density as a predictor of the regeneration stem density).

252 We included the adult communities among the predictors so as to evaluate their direct influence on 253 regeneration, potentially by means of their offspring. Thus, we evaluated stem density, observed 254 species richness, density of vertebrate-dispersed trees, density of non-vertebrate-dispersed trees, 255 CWM-SM, and relative abundance of forest-specialist trees - measured in adults above each 256 regeneration community - as regeneration predictors. We also assessed the interaction between 257 neighbouring forest age and forest cover because we expected the effect of forest age to be 258 influenced by the amount of forest cover, for instance, old-growth species may become absent in 259 'old' forest patches in heavily deforested landscapes (Pardini et al. 2010; Banks-Leite et al. 2014).

260 To satisfy the model assumptions on error distributions, CWM-SM was log-transformed, and 261 relative abundance of forest-specialists was square-root transformed. Two plots without 'adult 262 trees' $(\mathrm{DBH} \geq 5 \mathrm{~cm})$ were dropped in these last two models, because for these plots it was impossible 263 to calculate seed-mass CWM and relative abundance of forest-specialists among 'adults'.

\section{RESULTS}

265

Within the $200 \mathrm{~m}^{2}$-plots, a total of 1033 trees with $\mathrm{DBH} \geq 5 \mathrm{~cm}$ (here referred to as 'adults') belonging to 94 species were identified and measured. Two plots (out of 108) presented no adults.

267 Correspondingly, in the $100 \mathrm{~m}^{2}$-subplots, we catalogued 3199 small individuals (DBH $<5 \mathrm{~cm}$, here 268 referred to as 'juveniles') belonging to 153 species. Every subplot presented juveniles. Fifteen 269 species were only found among adults, while 74 species were solely sampled among juveniles. Plant 270 conditions did not allow identification at the species level for 106 adults (10.7\%) and 366 juveniles $271 \quad(11.4 \%)$.

272 Combining vegetation plot data with the literature survey on species traits provided additional 273 context for the hypotheses we tested. We observed similar relative abundance of vertebrate274 dispersed juveniles within young-FC and old-FC contexts (respectively, 58.6\% and 60.2\%), and 275 both were slightly higher than relative abundances found with adults within young-FC and old-FC 
contexts (respectively, 40.3\% and 51.3\%). Juveniles presented smaller CWM of seed mass within

277 young-FC (median = 0.061 g.; IQR=0.031-0.124 g.) compared to old-FC (median = 0.097 g.;

278 IQR=0.048-0.257 g.); while adults presented greater and more variable CWM-SM within young-FC

279 and old-FC (0.045g./seed IQR=0.020-0.223, and 0.071g./seed IQR=0.030-0.108, respectively). Also,

280 it was notable that only $9.3 \%$ of adults and $7.5 \%$ of juveniles were categorised as forest-specialists

281 in plots with young-FC, while forest specialists contributed $17.1 \%$ of adults and $13.2 \%$ of juveniles

282 within old-FC.

\section{Stem density and species richness}

284 We did not find a significant association between stem densities of adults and juveniles (Table 1;

$285 \mathrm{p}=0.34)$. Forest age and amount significantly affected stem densities through their interaction:

286 increasing forest cover related to greater juvenile stem density only within young-FC (Table 1, Fig.

287 2a). However, individually, neither forest age nor forest amount significantly affected juvenile stem

288 densities ( $p=0.99$ and 0.34 , respectively). The interaction between age and amount of forest cover

289 was also a significant predictor of species richness in regeneration communities, with higher

290 response values associated with higher forest cover only within young-FC (Table 1, Fig. 2).

291 Nonetheless, for species richness, juvenile and adult communities were highly correlated

$292(\mathrm{P}=0.001)$.

After separating individuals according to seed dispersal syndrome, we found that none of the tested

294 variables was a good predictor of density for vertebrate-dispersed juveniles. Only a marginally

295 significant association was found with forest cover amount (Fig. 2-c). Densities of vertebrate

296 dispersed juveniles presented a small variance within restoration sites, and a large variance

297 between restoration sites, which was strongly related to random factors acting at the site level, but 298 not to the fixed variables (i.e. forest cover amount and age, and density of vertebrate dispersed 299 adults) (Table 1). In turn, densities of non-vertebrate dispersed juveniles, compared to vertebrate-

300 dispersed, were more weakly related to random factors and more strongly related to fixed factors

301 (Table 1). We found a significant effect from the interaction between forest cover amount and

302 forest cover age, in which higher densities of non-vertebrate dispersed juveniles related to more

303 forested landscapes only within young-FC contexts (Fig. 2-d). 


\begin{tabular}{|c|c|c|c|c|c|c|}
\hline model - regeneration communities & predictors & estimates & denDF & F-value & p-value & \\
\hline \multirow[t]{4}{*}{ a. stem density } & forest cover (\%) & 55.85 & 78 & 0.001 & 0.976 & \\
\hline & forest age ( $\geq 30 \mathrm{yrs}$ instead of $<30 \mathrm{yrs}$ ) & 10.13 & 25 & 0.000 & 0.999 & \\
\hline & stem density $(\mathrm{dbh} \geq 5 \mathrm{~cm})$ & 0.18 & 78 & 0.914 & 0.342 & \\
\hline & interaction forest cover and age & -69.99 & 78 & 5.816 & 0.018 & * \\
\hline \multirow[t]{4}{*}{ b. species richness } & forest cover (\%) & 17.97 & 78 & 0.851 & 0.359 & \\
\hline & forest age ( $\geq 30 \mathrm{yrs}$ instead of $<30 \mathrm{yrs}$ ) & 2.90 & 25 & 0.111 & 0.741 & \\
\hline & species richness $(\mathrm{dbh} \geq 5 \mathrm{~cm})$ & 0.34 & 78 & 11.714 & 0.001 & ${ }^{* *}$ \\
\hline & interaction forest cover and age & -20.43 & 78 & 7.371 & 0.008 & ** \\
\hline \multirow{4}{*}{ 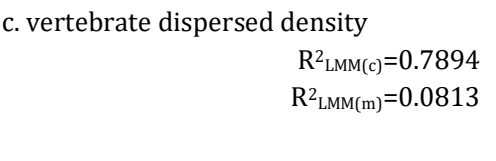 } & forest cover (\%) & 34.30 & 78 & 3.86 & 0.053 & \\
\hline & forest age ( $\geq 30 \mathrm{yrs}$ instead of $<30 \mathrm{yrs}$ ) & 4.36 & 25 & 0.062 & 0.806 & \\
\hline & vertebrate dispersed density $(\mathrm{dbh} \geq 5 \mathrm{~cm})$ & 0.06 & 78 & 0.062 & 0.804 & \\
\hline & interaction forest cover and age & -22.01 & 78 & 0.953 & 0.332 & \\
\hline \multirow{4}{*}{$\begin{array}{l}\text { d. non vertebrate-dispersed density } \\
\qquad \begin{array}{r}\mathrm{R}^{2}{ }_{\mathrm{LMM}(\mathrm{c})}=0.3801 \\
\mathrm{R}^{2}{ }_{\mathrm{LMM}(\mathrm{m})}=0.1319\end{array}\end{array}$} & forest cover (\%) & 15.83 & 78 & 0.623 & 0.432 & \\
\hline & forest age ( $\geq 30 \mathrm{yrs}$ instead of $<30 \mathrm{yrs}$ ) & 5.73 & 25 & 0.088 & 0.769 & \\
\hline & non vertebrate-dispersed density $(\mathrm{dbh} \geq 5 \mathrm{~cm})$ & 0.30 & 78 & 3.493 & 0.065 & \\
\hline & interaction forest cover and age & -33.59 & 78 & 7.048 & 0.010 & ** \\
\hline
\end{tabular}

Fig. 2. Observed densities in juveniles (dbh $<5 \mathrm{~cm}$ ) per $100 \mathrm{~m}^{2}$ plot ( $a, c$ and $d$ ) and species richness (b), as a function of forest cover amount and age (coloured points). Lines show models predictions (Table

312 1) +/- 95\% confidence intervals for young and old forest cover contexts. For these projections, we set 313 the analogous measurement of the respective predictor in the adult communities $(d b h \geq 5 \mathrm{~cm})$ at the 314 observed median value (i.e. 7.5 for "a.", 5.0 for "b." and 3.0 for "d.". No prediction was made for "c" 315 (vertebrate-dispersed stem densities) due to the lack of association with evaluated factors.

Disturbance sensitive traits: seed mass and habitat selectivity

317 We found significantly higher CWM seed mass among juveniles in landscapes with old forest. Such 318 association between older nearby forests and larger seeds reflected changes in absolute densities 319 for both extremes: small-seeded, and large-seeded, species. For instance, juveniles from all species 320 with seed mass below 0.001 g. presented average densities of 408 /ha for young-FC, and $243 /$ ha for 321 old-FC, while the average density of juveniles from all species with seed mass above $1 \mathrm{~g}$. was found 322 as 105/ha for young-FC and 225/ha for old FC. In addition, CWM of seed mass in the regeneration 323 community correlated to the seed mass observed among adults (Table 2-a and Fig. 3-a).

324 Similarly, we found higher relative abundance of forest-specialists in regeneration communities 325 when old forests were nearby, and when the relative abundance of forest-specialists was higher in the adult communities (Table 2 and Fig. 3-b). The average density of forest-specialist individuals 
was smaller within young-FC (165.0/ha) than within old-FC (389.7/ha); while generalists species were slightly rarer within old-FC (2572.1/ha) as compared to sites within young-FC (2797.5/ha).

Table 2. Effects of the forest cover amount, forest age, and tree community on the regeneration communities on the seed mass CWM-SM, and the relative abundance of forest specialists. ANOVA table resulting from linear mixed models with conditional $R^{2}$ (fixed and random factors) and marginal $332 \quad R^{2}$ (fixed factors only).

\subsection{0}

$\begin{array}{rrrl}76 & 2.66 & 0.107 & \\ 25 & 4.38 & 0.047 & * \\ 76 & 12.37 & 0.001 & * \\ 76 & 0.35 & 0.557 & \end{array}{ }^{*}$

b. relative abundance of forest specialists forest cover (\%) $\mathrm{R}^{2}{ }_{\text {LMM }(c)}=0.3992$ forest age $(\geq 30 \mathrm{yrs}$ instead of $<30 \mathrm{yrs})$ $\begin{array}{llll}-0.44 & 76 & 2.16 & 0.146\end{array}$ $\mathrm{R}^{2} \mathrm{LMM}(\mathrm{m})=0.1940$ rel. abund. of forest specialists $(\mathrm{dbh} \geq 5 \mathrm{~cm})$ $-0.66 \quad 25$

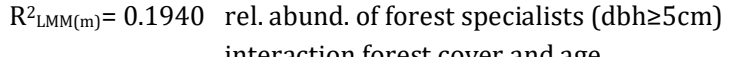
interaction forest cover and age $\quad 0.29 \quad 76$

Fig. 3 Observed CWM-SM in regeneration communities as a function of CWM-SM among adults (a), and relative density of forest-specialists among juveniles as a function of the relative abundance of forest-specialists among adults (b). Lines show models predictions (Table 1) $+/-95 \%$ confidence intervals for young and old forest cover contexts. For these projections, we set the forest cover to the observed medium value (i.e. 13.75\%).

\section{DISCUSSION}

339 Despite marked quantitative and compositional differences found among regeneration

340 communities growing beneath native tree-plantings, overall records indicate a meaningful forest

341 recovery. Across all sites, we identified 168 species and found an average of 3391 stems per

342 hectare, which reveals a nearly threefold increase for woody species richness and a nearly twofold

343 increase for stem density, found seven years after the plantation of 60 species in a density of 1,667

344 seedlings/ha. Still, similar initial restoration interventions resulted in markedly variable

345 trajectories. The relation between such quantitative and compositional differences and the

346 surrounding landscape revealed some unexpected patterns, but also corroborated some predictions

347 grounded by previous studies. We discuss these relationships, together with the practical

348 implications of our findings.

350 The relevance of considering the influence of the neighbouring forest history was corroborated by 351 the significant effect of the interaction between forest age and forest cover on the density and the 
species richness of juveniles. Here, the general expectation of denser seed rain in landscapes of

353 greater forest cover leading to a denser and richer regeneration (Holl 2007; but see Charles et al.

354 2019), was supported in the context of young forest cover, but not around forests that were older

355 than 30 years. Such a pattern suggests two possibilities: higher old forest cover is not consistently

356 improving the seed arrival in restoration sites; and/or seed rain around old forests are not

357 resulting in the establishment of denser or richer communities due to limitations on germination

358 and seedling survival (Reid and Holl 2013).

359 The possibility of regeneration communities being affected by variation in seed arrival due to

360 dispersal limitation is consistent with our results. We found the correlation between the amount of

361 forest cover and the density of regeneration communities to be dependent on the dispersal

362 syndrome. Accordingly, the rarity of non-vertebrate-dispersed trees is increased markedly when

363 young Brazilian Atlantic Forests gets older (Liebsch et al. 2008). On the other hand, the studied

364 region is marked by heavy forest fragmentation (Toledo et al. 2018b) and defaunation, with

365 negative consequences on seed dispersal (Galetti et al. 2013; Galetti et al. 2017). Defaunation can

366 play a crucial role in the recovery of tropical forests because the vast majority of tropical trees are

367 dispersed by animals (Howe and Smallwood, 1982). Thus, populations of numerous animal-

368 dispersed species may sometimes be trapped inside forest patches by the local absence of their

369 dispersers, which limits the cross-habitat spillover of zoochoric species. Hence, in comparison to

370 young-forest seed rains, old-forest seed-rains are likely least related to anemochoric trees, and

371 more affected by defaunation.

372 It is well documented that the early stages of regeneration of tropical forests is driven by strict

373 filters, resulting from the shortage of tree cover (Brancalion et al. 2019b). As well as forest age and

374 forest cover, we used 'adult' densities as predictors of tree cover at each restoration site.

375 Unexpectedly, we found that adult stem densities did not provide significant effects on juvenile

376 densities, neither for vertebrate-dispersed species nor for non-vertebrate-dispersed species.

377 Perhaps, the range of 'adult' stem densities will increase in the future, revealing the expected effect

378 on juvenile densities. The average 'adult' stem density in our sample was 478 individuals per

379 hectare, while Brancalion et al. (2019) compared stem densities up to 3,333 ind/ha.

380 The establishment of regeneration communities could also be influenced by limiting physico-

381 chemical and biological conditions at the sites, which can elevate mortality rates due to e.g.

382 dessication, competition and predation (Reid and Holl 2013). We intended that our sampling design 
reduced the variation in such conditions. However, our analysis clearly indicates that the relevance of tested predictors of densities and species richness (i.e. forest cover amount, forest-cover age and adult community density and composition) was mild compared to other factors varying between restoration sites, as demonstrated by the difference between conditional and marginal $\mathrm{R}^{2}$ values. In other words, the simplicity of the few predictors we used comes at the expense of a greater explanation of variance by fixed factors. It is possible that variables such as soil properties outweighed forest amount and age in explaining regeneration patterns (Table 1). Alternatively, or additionally, some unexplained variance could be related to the relative abundance of forest ages in the landscape, successional variation within forest age groups, and/or unmeasured forest configuration. Presumably, these features have been accounted at the restoration site level as random factors. Different scales at which to include forest cover and forest age (i.e. beyond the $200 \mathrm{~m}$ buffer we considered) could also lead to changed insights, perhaps depending on the dispersal capabilities of surrounding species. Interestingly, considering other buffers with our data would compromise the analysis we performed here: too small a buffer (e.g. $100 \mathrm{~m}$ ) would lead to zero forest cover in the surrounding landscape for 42 plots, out of the 108 in total, while too great a buffer (e.g. 800m) would mean that all landscapes had some 'old' forest. Regardless, our results suggest that knowing the age of surrounding forest, in addition to its cover, provides insight into the composition and structure of regeneration communities in restoration sites. This emphasises a likely requirement for future studies to consider more nuanced landscape descriptors and that using multiple aspects of forest cover data to predict ecological responses is a valuable tool for ecologists and/or restoration practitioners. We fully expect the suggested approach to be workable for restoration planners.

\section{Compositional indicators of disturbance sensitivity}

We have observed that the lack of neighbouring old-forests compromises, in comparison to historical conditions, the compositional recovery of forests under restoration. Habitat-generalists and small-seeded species (e.g. Baccharis dracunculifola, Myrcine coriacea, Schinnus terebentifolia and Vernonanthura polyanthes) dominated regeneration communities in restoration sites with young neighbouring forest cover. These results are consistent with theoretical predictions of 411 dependence between local diversity and the landscape species pool (Rickflefs 1987, Tscharntke et 412 al. 2012). Indeed, forest-specialist juveniles were rarer in restoration sites within landscapes where 413 forests were completely absent 10-30 years earlier. In turn, large-seeded juveniles were rarer in 414 young forests, whereas large-seeded seedlings are more competitive under shady conditions 415 beneath mature forests (Foster and Janson 1985; Lohbeck et al. 2015). Also, large-seeded zoochoric 
trees require large frugivores to recolonize young forests, and large seed dispersers tend to become

417 locally extinct under conditions of extreme deforestation (Galetti et al. 2017).

418 Furthermore, these patterns that relate to seed-mass and habitat-selectivity are likely connected to

419 a broader functional trend: studies have reported increased rarity of 'disturbance-sensitive' trees

420 (Tabarelli et al. 2004) as well as the overabundance of 'disturbance-tolerant' trees (Prieto et al.

421 2014) resulting from forest fragmentation. Forest specialists are more sensitive to degradation as a

422 result of specialization to narrow environmental niches, characterized by dark understorey with

423 relatively stable humidity and temperature (Edwards et al. 2014). In contrast, Laurence et al.

424 (2018) include fast growing pioneer trees among the 'disturbance-lovers', which are habitat

425 generalist that are common within young second growth (Liebsch et al. 2008) and the

426 anthropogenic matrix (Lopez-Toledo and Martinez-Ramos 2011; Zahawi et al. 2013; Reid et al.

427 2015).

428 We have observed that these generalist species tend to dilute populations of disturbance-sensitive 429 tree species, as predicted by the 'concentration and dilution hypothesis' (Tscharntke et al. 2012), in 430 well-forested landscapes that only presented young forests. Such a pattern supports a concerning 431 possibility: remotely sensed data indicating regional expansions of tropical forests, as verified by 432 Lira et al. (2012), Rezende et al. (2015), Rudel et al. (2016), and Molin et al. (2017) may sometimes 433 reveal the rise of impoverished forests, lacking species groups that are particularly targeted by 434 restoration programs. Thus, robust areal recovery of the forest-cover may not be followed by a 435 comprehensive ecological recovery in heavy degraded landscapes. In other words, ecological 436 inferences based on satellite data require ground-truthing through biological surveys, particularly 437 in vastly deforested rural landscapes, in which forest cover tends to be increasingly impoverished 438 in forest-specialist species (Tabarelli 2008; Pardini et al. 2010; Benchimol et al. 2017). Implications for restoration practices

440 Our models indicate that greater stem density and species richness are related to higher forest 441 cover when young forests are nearby, which is promoted by abundant non-vertebrate-dispersed 442 trees. Proximity to young forest patches is therefore opportune when fast tree-cover recovery is 443 among the targets of the restoration intervention, for instance in classic goals related to reducing 444 soil erosion and landslide risks (Stanturf et al. 2014).

445 We observed composition of adult communities consistently affecting the species assemblage in the 446 respective regeneration communities, as observed with species richness, CWM of seed mass, and 
relative abundance of forest specialist $(\mathrm{p}=0.001, \mathrm{p}<0.001$, and $\mathrm{p}=0.036$; respectively). These results corroborate that the planted species-pool can mitigate, or intensify, limitations from the surrounding diversity. Consequently, high diversity tree-plantings (Rodrigues et al. 2009;

450 Brancalion et al. 2010) can alleviate constraints resulting from the loss of functional connectivity 451 between restoration sites and mature forests. In this case, the selection of species for restoration 452 plantings should be carefully planned in favour of vulnerable species (Hooper et al. 2005;

453 Brancalion et al. 2018)), in spite of seed/seedling market tendencies (Brancalion et al. 2018), which 454 privileges small seeded species. We highlight this idea on account of the increasing weight of recommendation in the literature that tropical forest restoration be focused on passive, rather than active, restoration (e.g. Chazdon and Uriarte, 2017; Meli et al. 2017, but see Reid et al. 2018; and Gardon et al. 2020). Our results ground the recommendation of active restoration on sites that are too far from old-growth forests (i.e. distance $>200 \mathrm{~m}$ ), in which manipulating the species pool is likely necessary.

Predictive models on tropical forest recovery have been developed to assist global and national scale conservation policies. In particular, findings from Brancalion et al. (2019), Rozendaal et al. (2019), and Strassburg et al. (2019) supported the amount of neighbouring forest cover as a good predictor of forest recovery. Perhaps their models could also be improved by accounting for the age of the forest patches. However, these three studies adopted a 5-Km buffer to measure the forest cover. Presumably, they have captured a different set of social, abiotic and ecological drivers of forest recovery that are also related to the landscape forest cover, but that are better detected at a considerably larger scale. Our findings are better suited for restoration planning in landscape scale, which ideally happens after global and national guidelines have been followed.

\section{CONCLUSION}

470 We evaluated tree communities thatckresulted from similar native-tree plantings in landscapes 471 with old forests, and landscapes comprising young forests only. We found that faster recovery of 472 tree cover and species richness is likely to take place in landscapes with a considerable amount of 473 young forests (i.e. $>25 \%$ of land-cover), due an increased regeneration of non-vertebrate dispersed, 474 small seeded, and habitat generalist trees. However, disturbance-sensitive species i.e. vertebrate 475 dispersed, moist-forest specialists are more likely to be missing in the absence of nearby old 476 forests. Our results demonstrate that the history of neighbouring forests i.e. amount of cover and 477 age) is valuable information for landscape restoration planners. 
479 The authors gratefully acknowledge financial support (grant 2014/20206-5) of São Paulo Research

480 Foundation (FAPESP) and cooperation from Biodiversity and Natural Resources Coordination

481 (CBRN -São Paulo state). We thank Jean Paul Metzger, José Torezan, Ricardo Rodrigues and Vânia

482 Pivello for valuable comments on earlier drafts of this article.

\section{REFERENCES}

Asner, GP, Rudel, TK, Aide, TM, DeFries, R, Emerson, R. (2009) A contemporary assessment of change in humid tropical forests. Conservation Biology 23:1386-1395

Banks-Leite, C, Pardini, R, Tambosi, LR, Pearse, WD, Bueno, AA, Bruscagin, RT, Condez, TH, Dixo, M, Igari, AT, Martensen, AC, Metzger, JP (2014) Using ecological thresholds to evaluate the costs and benefits of set-asides in a biodiversity hotspot. Science 345:1041-1045

Benchimol, M, Mariano-Neto, E, Faria, D, Rocha-Santos, L, de Souza Pessoa, M, Gomes, FS, Talora, DC, Cazetta, E (2017) Translating plant community responses to habitat loss into conservation practices: Forest cover matters. Biological conservation 209:499-507

Brancalion, PHS, Rodrigues, RR, Gandolfi, S, Kageyama, PY, Nave, AG, Gandara, FB, Barbosa, LM, Tabarelli, M (2010) Instrumentos legais podem contribuir para a restauração de florestas tropicais biodiversas. Revista Árvore, 34:455-470 (2018) Maximizing biodiversity conservation and carbon stocking in restored tropical forests. Conservation Letters 11:p.e12454

Brancalion, P.H., Niamir, A., Broadbent, E., Crouzeilles, R., Barros, F.S., Zambrano, A.M.A., Baccini, A., Aronson, J., Goetz, S., Reid, J.L. and Strassburg, B.B., (2019a). Global restoration opportunities in tropical rainforest landscapes. Science advances, 5(7), p.eaav3223.

501 Brancalion, P.H., Campoe, O., Mendes, J.C.T., Noel, C., Moreira, G.G., van Melis, J., Stape, J.L. and Guillemot, J., 502 (2019b). Intensive silviculture enhances biomass accumulation and tree diversity recovery in tropical forest 503 restoration. Ecological applications, 29(2), p.e01847.

504 Catterall, C.P., 2018. Fauna as passengers and drivers in vegetation restoration: A synthesis of processes and 505 evidence. Ecological Management \& Restoration, 19, pp.54-62. regions. Landscape Ecology 34:1-16

509 Chazdon, RL (2008) Beyond deforestation: restoring forests and ecosystem services on degraded 510 lands. Science 320:1458-1460 
Chazdon, RL (2014) Second growth: the promise of tropical forest regeneration in an age of deforestation. University of Chicago Press

513 Chazdon, RL, Guariguata, MR (2016) Natural regeneration as a tool for large-scale forest restoration in the tropics: prospects and challenges. Biotropica 48:716-730

Chazdon, RL, Uriarte, M (2016) Natural regeneration in the context of large-scale forest and landscape restoration in the tropics. Biotropica 48:709-715

Chase, MW, Christenhusz, MJM, Fay, MF, Byng, JW, Judd, WS, Soltis, DE, Mabberley, DJ, Sennikov, AN, Soltis, PS, Stevens, PF (2016) An update of the Angiosperm Phylogeny Group classification for the orders and families of flowering plants: APG IV. Botanical Journal of the Linnean Society 181:1-20

Costa, JB, Melo, FP, Santos, BA, Tabarelli, M (2012) Reduced availability of large seeds constrains

Atlantic forest regeneration. Acta Oecologica 39:61-66

\section{Crouzeilles, R. and Curran, M., 2016. Which landscape size best predicts the influence of forest cover on} restoration success? A global meta-analysis on the scale of effect. Journal of Applied Ecology, 53(2), pp.440448.

de la Peña-Domene, M., Minor, E.S. and Howe, H.F., 2016. Restored connectivity facilitates recruitment by an endemic large-seeded tree in a fragmented tropical landscape. Ecology, 97(9), pp.2511-2517.

534 Edwards, DP, Tobias, JA, Sheil, D, Meijaard, E, Laurance, WF (2014) Maintaining ecosystem function

Durigan, G, Guerin, N, da Costa, JNMN (2013) Ecological restoration of Xingu Basin headwaters: motivations, engagement, challenges and perspectives. Philosophical Transactions of the Royal Society of London B: Biological Sciences 368:20120165

Dean, W (1997) With broadax and firebrand: the destruction of the Brazilian Atlantic Forest. Univ of California Press and services in logged tropical forests. Trends in ecology \& evolution 29:511-520

Ferraz, SF, Ferraz, KM, Cassiano, CC, Brancalion, PHS, da Luz, DT, Azevedo, TN, Tambosi, LR, Metzger, JP (2014) How good are tropical forest patches for ecosystem services provisioning?. Landscape ecology 29:187-200

540 tropical woody plants. Ecology 66:773-780

541 Galetti, M, Guevara, R, Côrtes, MC, Fadini, R, Von Matter, S, Leite, AB, Labecca, F, Ribeiro, T, Carvalho, 542 CS, Collevatti, RG, Pires, MM (2013) Functional extinction of birds drives rapid evolutionary

543 changes in seed size. Science 340:1086-1090

544 Galetti, M, Pires, AS, Brancalion, PH, Fernandez, FA (2017) Reversing defaunation by trophic 545 rewilding in empty forests. Biotropica 49:5-8

546 Gardon, F.R., dos Santos, R.F. and Rodrigues, R.R., 2020. Brazil's forest restoration, biomass and carbon stocks: 547 A critical review of the knowledge gaps. Forest Ecology and Management, 462, p.117972. 
Gibson, L, Lee, TM, Koh, LP, Brook, BW, Gardner, TA, Barlow, J, Peres, CA, Bradshaw, CJ, Laurance, WF, Lovejoy, TE, Sodhi, NS (2011) Primary forests are irreplaceable for sustaining tropical biodiversity. Nature 478:378

551 Hijmans, RJ, Cameron, SE, Parra, JL, Jones, PG, Jarvis, A (2005) Very high resolution interpolated 552 climate surfaces for global land areas. International journal of climatology, 25:1965-1978

553 Holl, KD (2007) Old field vegetation succession in the neotropics. In: Hobbs RJ (ed) Old fields: 554 Dynamics and restoration of abandoned farmland, pp.93-118

555 Holl, KD (2017) Restoring tropical forests from the bottom up. Science 355:455-456

556 Howe, HF, Smallwood, J (1982) Ecology of seed dispersal. Annual review of ecology and systematics $557 \quad 13: 201-228$

558 Hooper, E, Legendre, P, Condit, R (2005) Barriers to forest regeneration of deforested and 559 abandoned land in Panama. Journal of Applied Ecology 42:1165-1174

560 Kauano, ÉE, Cardoso, FC, Torezan, JMD, Marques, MC (2013) Micro-and meso-scale factors affect the 561 restoration of Atlantic Forest. Natureza \& Conservação 11:145-151

562 Kueffer, C, Kaiser-Bunbury, CN (2014) Reconciling conflicting perspectives for biodiversity 563 conservation in the Anthropocene. Frontiers in Ecology and the Environment 12:131-137

564 Lamb, D, Erskine, PD, Parrotta, JA (2005) Restoration of degraded tropical forest landscapes. 565 Science 310:1628-1632

566 Liebsch, D, Marques, MC, Goldenberg, R (2008) How long does the Atlantic Rain Forest take to 567 recover after a disturbance? Changes in species composition and ecological features during 568 secondary succession. Biological Conservation 141:1717-1725

569 Lira, PK, Tambosi, LR, Ewers, RM, Metzger, JP (2012) Land-use and land-cover change in Atlantic 570 Forest landscapes. Forest Ecology and Management 278:80-89

571 Lohbeck, M, Lebrija-Trejos, E, Martínez-Ramos, M, Meave, JA, Poorter, L, Bongers, F (2015)

572 Functional trait strategies of trees in dry and wet tropical forests are similar but differ in their 573 consequences for succession. PloS one 10:p.e0123741

574 Lopez-Toledo, L, Mariínez-Ramos, M (2011) The soil seed bank in abandoned tropical pastures: 575 source of regeneration or invasion? Revista Mexicana de Biodiversidad 82:663-678

576 Malhi, Y, Gardner, TA, Goldsmith, GR, Silman, MR, Zelazowski, P (2014) Tropical forests in the 577 Anthropocene. Annual Review of Environment and Resources 39:125-159

578 Meli, P, Holl, KD, Benayas, JMR, Jones, HP, Jones, PC, Montoya, D, Mateos, DM (2017) A global review 579 of past land use, climate, and active vs. passive restoration effects on forest recovery. PloS one 12:

580 p.e0171368 
Middendorp, RS, Pérez, AJ, Molina, A, Lambin, EF (2016) The potential to restore native woody plant richness and composition in a reforesting landscape: a modeling approach in the Ecuadorian Andes. Landscape ecology 31:1581-1599

584

585

Molin, PG, Gergel, SE, Soares-Filho, BS, Ferraz, SF (2017) Spatial determinants of Atlantic Forest loss and recovery in Brazil. Landscape ecology 32:857-870

Nakagawa, S, Johnson, PC, Schielzeth, H (2017) The coefficient of determination R 2 and intra-class correlation coefficient from generalized linear mixed-effects models revisited and expanded. Journal of the Royal Society Interface 14:p.20170213

Pardini, R, de Arruda Bueno, A, Gardner, TA, Prado, PI, Metzger, JP (2012) Beyond the fragmentation threshold hypothesis: regime shifts in biodiversity across fragmented landscapes. PloS one 5: p.e13666

Olson, DM, Dinerstein, E, Wikramanayake, ED, Burgess, ND, Powell, GV, Underwood, EC, D'amico, JA, Itoua, I, Strand, HE, Morrison, JC, Loucks, CJ (2001) Terrestrial Ecoregions of the World: A New Map of Life on EarthA new global map of terrestrial ecoregions provides an innovative tool for conserving biodiversity. BioScience 51:pp.933-938

Poorter, L, Bongers, F, Aide, TM, Zambrano, AMA, Balvanera, P, Becknell, JM, Boukili, V, Brancalion, PH, Broadbent, EN, Chazdon, RL, Craven, D (2016) Biomass resilience of Neotropical secondary forests. Nature 530:211

Prieto, PV, Sansevero, JB, Garbin, ML, Braga, JM, Rodrigues, PJ (2014) Edge effects of linear canopy openings on understorey communities in a lowland Atlantic tropical forest. Applied Vegetation Science 17:121-128

Rezende, CL, Uezu, A, Scarano, FR, Araujo, DSD (2015) Atlantic Forest spontaneous regeneration at landscape scale. Biodiversity and conservation 24:2255-2272

Reid, JL, Holl, KD (2013) Arrival= survival. Restoration Ecology 21:153-155

Reid, JL, Holl, KD, Zahawi, RA (2015) Seed dispersal limitations shift over time in tropical forest restoration. Ecological Applications 25:1072-1082

Reid, J.L., Fagan, M.E. and Zahawi, R.A., 2018. Positive site selection bias in meta-analyses comparing natural regeneration to active forest restoration. Science advances, 4(5), p.eaas9143.

Ricklefs, RE (1987) Community diversity: relative roles of local and regional processes. Science 235:167-171

Rodrigues, RR, Lima, RA, Gandolfi, S, Nave, AG (2009) On the restoration of high diversity forests: 30 years of experience in the Brazilian Atlantic Forest. Biological conservation 142:1242-1251

Rouse J, Haas, RH, Schell, JA, Deering, DW (1974) Monitoring vegetation systems in the Great Plains with ERTS. In Proceedings of the Third ERTS Symposium; NASA, Washington, NASA SP-351: 309317

Rozendaal, D.M., Bongers, F., Aide, T.M., Alvarez-Dávila, E., Ascarrunz, N., Balvanera, P., Becknell, J.M., Bentos, T.V., Brancalion, P.H., Cabral, G.A. and Calvo-Rodriguez, S., 2019. Biodiversity recovery of Neotropical secondary forests. Science advances, 5(3), p.eaau3114. 
Rudel, TK, Sloan, S, Chazdon, R, Grau, R (2016) The drivers of tree cover expansion: Global, temperate, and tropical zone analyses. Land Use Policy 58:502-513

Shackelford, N., Starzomski, B.M., Banning, N.C., Battaglia, L.L., Becker, A., Bellingham, P.J., Bestelmeyer, B., Catford, J.A., Dwyer, J.M., Dynesius, M. and Gilmour, J., 2017. Isolation predicts compositional change after discrete disturbances in a global meta-study. Ecography, 40(11), pp.1256-1266.

Souza, JT, Ferraz, EMN, Albuquerque, UP, Araújo, EL (2014) Does proximity to a mature forest contribute to the seed rain and recovery of an abandoned agriculture area in a semiarid climate? Plant Biology 16:748-756

Scudeller, VV, Martins, FR, Shepherd, GJ (2001) Distribution and abundance of arboreal species in the atlantic ombrophilous dense forest in Southeastern Brazil. Plant ecology 152:185-199

Strassburg, B.B., Beyer, H.L., Crouzeilles, R., Iribarrem, A., Barros, F., de Siqueira, M.F., Sánchez-Tapia, A., Balmford, A., Sansevero, J.B.B., Brancalion, P.H.S. and Broadbent, E.N., 2019. Strategic approaches to restoring ecosystems can triple conservation gains and halve costs. Nature ecology \& evolution, 3(1), pp.62-70.

Suding, K, Higgs, E, Palmer, M, Callicott, JB, Anderson, CB, Baker, M, Gutrich, JJ, Hondula, KL, LaFevor, MC, Larson, BM, Randall, A (2015) Committing to ecological restoration. Science 348:638640

Stanturf, JA, Palik, BJ, Williams, MI, Dumroese, RK, Madsen, P (2014) Forest restoration paradigms. Journal of sustainable forestry 33:161-S194

Tabarelli, M, Da Silva, JMC, Gascon, C (2004) Forest fragmentation, synergisms and the impoverishment of neotropical forests. Biodiversity \& Conservation 13:1419-1425

Tabarelli, M, Lopes, AV, Peres, CA (2008) Edge-effects drive tropical forest fragments towards an early-successional system. Biotropica 40:657-661

Tambosi, L.R., Martensen, A.C., Ribeiro, M.C. and Metzger, J.P., 2014. A framework to optimize biodiversity restoration efforts based on habitat amount and landscape connectivity. Restoration Ecology, 22(2), pp.169177.

Toledo, RM, Santos, RF, Baeten, L, Perring, MP, Verheyen, K (2018a). Soil properties and neighbouring forest cover affect above-ground biomass and functional composition during tropical forest restoration. Applied Vegetation Science 21:179-189

Toledo, RM, Santos, RF, Verheyen, K, Perring, MP (2018b) Ecological restoration efforts in tropical rural landscapes: Challenges and policy implications in a highly degraded region. Land Use Policy $75: 486-493$

Tscharntke, T, Tylianakis, JM, Rand, TA, Didham, RK, Fahrig, L, Batary, P, Bengtsson, J, Clough, Y, Crist, TO, Dormann, CF, Ewers, RM (2012) Landscape moderation of biodiversity patterns and processes-eight hypotheses. Biological Reviews 87:661-685

Wuethrich, B (2007) Reconstructing Brazil's Atlantic Rainforest. Science 315:1070-1072

Zahawi, RA, Holl, KD, Cole, RJ, Reid, JL (2013) Testing applied nucleation as a strategy to facilitate tropical forest recovery. Journal of Applied Ecology 50:88-96 


\section{Supplementary Information}

Toledo et al. Restoring tropical forest composition is more difficult, but recovering tree-cover is faster, when neighbouring forests are young, Landscape Ecology

Online resource 1. Our study region is located in São Paulo State, Brazil. We surveyed watersheds in the
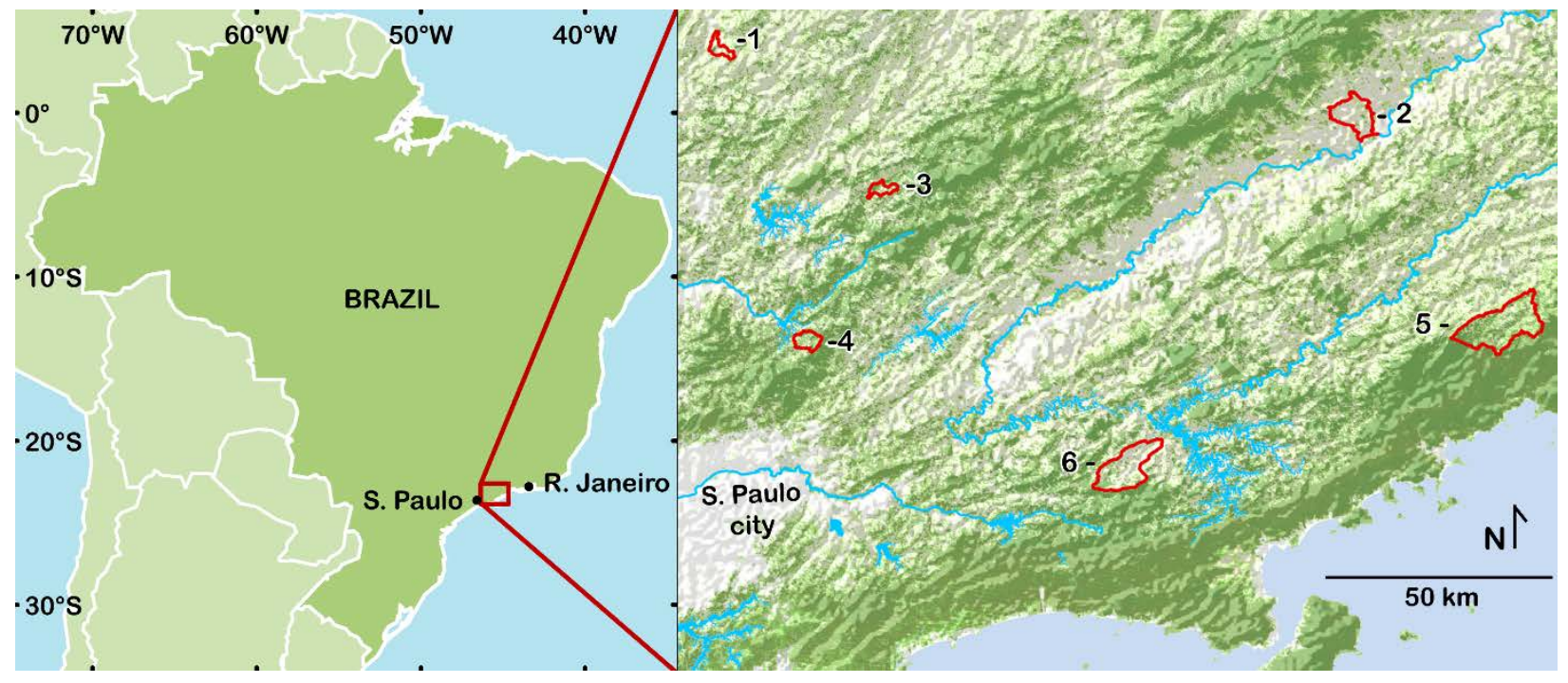

\section{Supplementary Information}

Toledo et al. Restoring tropical forest composition is more difficult, but recovering tree-cover is faster, when neighbouring forests are young, Landscape Ecology

Online resource 2. Statistics describing each research site: a. average forest cover at site level (200-m-wide buffer), b. forest age group, c. average relative abundance of old forests within forested areas at site level, d. average density of juvenile at site level (per $100 \mathrm{~m}^{2}$ ), e. average density of non-vertebrate dispersed juveniles at site level (per $100 \mathrm{~m}^{2}$ ), f. e. average density of vertebrate dispersed juveniles at site level (per $100 \mathrm{~m}^{2}$ ), g. average species richness per juvenile plot $\left(100 \mathrm{~m}^{2}\right)$, h. CWM Seed-mass (mg./1000 seeds), and i. average relative abundance of forest specialists within juveniles at site level.

\begin{tabular}{|c|c|c|c|c|c|c|c|c|c|}
\hline $\begin{array}{c}\text { Watershed / } \\
\text { site }\end{array}$ & $\begin{array}{c}\text { a. forest } \\
\text { cover }\end{array}$ & $\begin{array}{c}\text { b. forest } \\
\text { age }\end{array}$ & $\begin{array}{c}\text { c. old- } \\
\text { forest } \\
\text { ratio }\end{array}$ & $\begin{array}{c}\text { d. juvenile } \\
\text { density }\end{array}$ & $\begin{array}{c}\text { e. non- } \\
\text { vertebrate } \\
\text { dispersed } \\
\text { density }\end{array}$ & $\begin{array}{c}\text { f. } \\
\text { vertebrate } \\
\text { dispersed } \\
\text { density }\end{array}$ & $\begin{array}{c}\text { g. species } \\
\text { richness }\end{array}$ & $\begin{array}{c}\text { h. CWM } \\
\text { seed mass }\end{array}$ & $\begin{array}{c}\text { i. relative } \\
\text { abundance } \\
\text { forest- } \\
\text { specialists }\end{array}$ \\
\hline Cunha 1 & $13.9 \%$ & $<$ 30yrs. & $0 \%$ & 60 & 16.5 & 29.5 & 16.5 & 42.9 & $2.9 \%$ \\
\hline Cunha 2 & $30.5 \%$ & $<30$ yrs. & $0 \%$ & 45.5 & 11 & 27 & 13 & 89 & $7.6 \%$ \\
\hline Cunha 5 & $9.4 \%$ & $<30$ yrs. & $0 \%$ & 17.8 & 8.3 & 8 & 7 & 8.5 & $5.8 \%$ \\
\hline Cunha 7 & $49.3 \%$ & $<$ 30yrs. & $0 \%$ & 36.5 & 15.3 & 16.5 & 16 & 141.5 & $5.7 \%$ \\
\hline Cunha 8 & $20.8 \%$ & $<30$ yrs. & $0 \%$ & 48.5 & 11 & 27.3 & 15 & 67.2 & $8.0 \%$ \\
\hline Cunha 9 & $4.0 \%$ & $<30$ yrs. & $0 \%$ & 28 & 10.5 & 15.8 & 11 & 25.9 & $7.5 \%$ \\
\hline Guaratinguetá 2 & $0.3 \%$ & $<30$ yrs. & $0 \%$ & 9.8 & 4.8 & 3 & 8 & 208.8 & $20.7 \%$ \\
\hline N. Paulista 5 & $3.3 \%$ & $<30$ yrs. & $0 \%$ & 20 & 8 & 11.5 & 9 & 57.3 & $25.5 \%$ \\
\hline Paraibuna 2 & $3.9 \%$ & $<30$ yrs. & $0 \%$ & 8.5 & 5.3 & 2.8 & 5 & 31.1 & $2.6 \%$ \\
\hline Socorro 3 & $17.4 \%$ & $<30$ yrs. & $0 \%$ & 21.8 & 13 & 5.5 & 11.3 & 169.9 & $4.3 \%$ \\
\hline
\end{tabular}




\begin{tabular}{|c|c|c|c|c|c|c|c|c|c|}
\hline Average & $15.3 \%$ & < 30yrs. & $0 \%$ & 29.6 & 10.4 & 14.7 & 11.2 & 84.2 & 9.1 \\
\hline Cunha 3 & $7.4 \%$ & $\geq 30$ yrs. & $58.1 \%$ & 31.5 & 20.3 & 11 & 10.8 & 32 & $0.0 \%$ \\
\hline Cunha 4 & $27.3 \%$ & $\geq 30$ yrs. & $92.1 \%$ & 15.5 & 6.6 & 8.3 & 9 & 153.4 & $8.0 \%$ \\
\hline Cunha 6 & $28.1 \%$ & $\geq 30 \mathrm{yrs}$ & $78.7 \%$ & 43.3 & 11.8 & 27.5 & 15.8 & 290.2 & $1.2 \%$ \\
\hline Cunha 10 & $21.0 \%$ & $\geq 30 \mathrm{yrs}$ & $97.1 \%$ & 52.3 & 18.5 & 27.3 & 20 & 58.3 & $9.7 \%$ \\
\hline Cunha 11 & $30.1 \%$ & $\geq 30 \mathrm{yrs}$ & $67.0 \%$ & 37.8 & 3.5 & 32.3 & 11.8 & 194.4 & $5.4 \%$ \\
\hline Guaratinguetá 1 & $19.8 \%$ & $\geq 30 \mathrm{yrs}$ & $69.4 \%$ & 22.5 & 8.8 & 7 & 12.8 & 271.4 & $24.1 \%$ \\
\hline Guaratinguetá 3 & $1.6 \%$ & $\geq 30$ yrs. & $41.7 \%$ & 55.5 & 10.5 & 39.5 & 17.3 & 41 & $20.2 \%$ \\
\hline Joanópolis 1 & $14.5 \%$ & $\geq 30$ yrs. & $61.8 \%$ & 32 & 11.8 & 14.8 & 15.3 & 318.6 & $36.8 \%$ \\
\hline Joanópolis 2 & $7.6 \%$ & $\geq 30 y r s$ & $74.8 \%$ & 18.5 & 9.3 & 9 & 7 & 48.7 & $20.2 \%$ \\
\hline Joanópolis 3 & $26.5 \%$ & $\geq 30 \mathrm{yrs}$ & $75.4 \%$ & 16.3 & 8.8 & 6.5 & 9.3 & 125.7 & $20.7 \%$ \\
\hline N. Paulista 1 & $25.9 \%$ & $\geq 30$ yrs. & $69.2 \%$ & 22.5 & 7.3 & 14.3 & 10.8 & 172.4 & $15.9 \%$ \\
\hline N. Paulista 2 & $35.8 \%$ & $\geq 30 y r s$ & $56.0 \%$ & 16.5 & 8.5 & 6.3 & 9.5 & 311.1 & $6.0 \%$ \\
\hline N. Paulista 3 & $17.1 \%$ & $\geq 30 y r s$ & $55.1 \%$ & 23.3 & 9.3 & 13.5 & 9.8 & 116.2 & $26.1 \%$ \\
\hline N. Paulista 4 & $32.5 \%$ & $\geq 30$ yrs. & $86.5 \%$ & 26.8 & 18.3 & 6.8 & 8 & 193.7 & $11.3 \%$ \\
\hline Paraibuna 1 & $9.3 \%$ & $\geq 30$ yrs. & $41.9 \%$ & 24.5 & 4.5 & 19 & 8.3 & 46.9 & $18.9 \%$ \\
\hline Socorro 1 & $6.30 \%$ & $\geq 30 \mathrm{yrs}$ & $100.0 \%$ & 18.8 & 7.3 & 8.5 & 11 & 662.4 & $9.1 \%$ \\
\hline Socorro 2 & $2.20 \%$ & $\geq 30$ yrs. & $18.3 \%$ & 46.3 & 18.3 & 24.8 & 12.8 & 295.3 & $6.9 \%$ \\
\hline Average & $18.40 \%$ & $\geq 30$ yrs. & $67.2 \%$ & 29.6 & 10.8 & 16.2 & 11.7 & 196 & $14.1 \%$ \\
\hline
\end{tabular}

679 Supplementary Information

680 Toledo et al. Restoring tropical forest composition is more difficult, but recovering tree-cover is faster, when 681 neighbouring forests are young, Landscape Ecology

682

683 Online resource 3. Sampled species, and their habitat selectivity category, specific seed mass, seed dispersal 684 syndrome and number of individual in two size categories ( $\mathrm{DBH}<5 \mathrm{~cm}$ and $\mathrm{DBH} \geq 5 \mathrm{~cm}$ ).

\begin{tabular}{|c|c|c|c|c|c|c|}
\hline Família & Espécie & Habitat & mg./seed & $\begin{array}{l}\text { Dispersal } \\
\text { Syndrome }\end{array}$ & N. $\mathrm{DBH} \geq 5$ & N. $\mathrm{DBH}<5$ \\
\hline Anacardiaceae & Astronium fraxinifolium & generalists & 31.7 & non-vertebrate & 1 & 2 \\
\hline Anacardiaceae & Astronium graveolens & generalists & 29 & non-vertebrate & 0 & 1 \\
\hline Anacardiaceae & Lithrea molleoides & generalists & 47.6 & vertebrate & 1 & 1 \\
\hline Anacardiaceae & Schinus terebinthifolia & generalists & 18.1 & vertebrate & 49 & 155 \\
\hline Anacardiaceae & Tapirira guianensis & generalists & 26 & vertebrate & 1 & 1 \\
\hline Annonaceae & Annona cacans & specialists & 186.2 & vertebrate & 2 & 7 \\
\hline Annonaceae & Guatteria australis & generalists & 1.6 & vertebrate & 2 & 1 \\
\hline Apocynaceae & Aspidosperma olivaceum & specialists & 200 & non-vertebrate & 0 & 1 \\
\hline Apocynaceae & Tabernaemontana catharinensis & generalists & 147.1 & vertebrate & 0 & 9 \\
\hline Araliaceae & Dendropanax cuneatus & generalists & 5.9 & vertebrate & 1 & 0 \\
\hline Araucariaceae & Araucaria angustifolia & specialists & 6666.7 & vertebrate & 3 & 5 \\
\hline Arecaceae & Euterpe edulis & specialists & 1298.7 & vertebrate & 0 & 11 \\
\hline Arecaceae & Syagrus romanzoffiana & generalists & 7142.9 & vertebrate & 0 & 6 \\
\hline Asteraceae & Baccharis dracunculifolia & generalists & 0.2 & non-vertebrate & 48 & 248 \\
\hline Asteraceae & Chromolaena laevigata & generalists & 0.3 & non-vertebrate & 27 & 42 \\
\hline Asteraceae & Dasyphyllum spinescens & generalists & 0.5 & non-vertebrate & 0 & 3 \\
\hline Asteraceae & Dasyphyllum brasiliense & specialists & 0.5 & non-vertebrate & 5 & 0 \\
\hline Asteraceae & Moquiniastrum polymorphum & generalists & 0.5 & non-vertebrate & 1 & 5 \\
\hline Asteraceae & Vernonanthura polyanthes & generalists & 1.6 & non-vertebrate & 19 & 203 \\
\hline Bignoniaceae & Cybistax antisyphilitica & generalists & 36.01 & non-vertebrate & 0 & 1 \\
\hline Bignoniaceae & Handroanthus chrysotrichus & generalists & 11.6 & non-vertebrate & 1 & 1 \\
\hline Bignoniaceae & Jacaranda mimosifolia & generalists & 11.7 & non-vertebrate & 0 & 1 \\
\hline Bignoniaceae & Handroanthus ochraceus & generalists & 13.9 & non-vertebrate & 0 & 3 \\
\hline Bignoniaceae & Handroanthus serratifolius & generalists & 125 & non-vertebrate & 0 & 2 \\
\hline Bignoniaceae & Tecoma stans & generalists & 6.9 & non-vertebrate & 1 & 1 \\
\hline Bixaceae & Bixa orellana & generalists & 25 & vertebrate & 0 & 1 \\
\hline Boraginaceae & Cordia ecalyculata & generalists & 185.2 & vertebrate & 4 & 0 \\
\hline Boraginaceae & Cordia myxa & generalists & 492.6 & vertebrate & 15 & 13 \\
\hline Boraginaceae & Cordia superba & generalists & 303 & vertebrate & 0 & 4 \\
\hline Calophyllaceae & Calophyllum brasiliense & generalists & 6250 & vertebrate & 0 & 1 \\
\hline Cannabaceae & Trema micrantha & generalists & 7 & vertebrate & 8 & 3 \\
\hline
\end{tabular}




\begin{tabular}{|c|c|c|c|c|c|c|}
\hline Família & Espécie & Habitat & mg./seed & $\begin{array}{c}\text { Dispersal } \\
\text { Syndrome }\end{array}$ & N. DBH $\geq 5$ & N. DBH $<5$ \\
\hline Cardiopteridaceae & Citronella gongonha & generalists & 90.9 & vertebrate & 3 & 16 \\
\hline Caricaceae & Jaracatia spinosa & generalists & 34.8 & vertebrate & 1 & 0 \\
\hline Celastraceae & Maytenus aquifolia & specialists & 294.1 & vertebrate & 0 & 1 \\
\hline Celastraceae & Maytenus gonoclada & generalists & 13.5 & vertebrate & 0 & 3 \\
\hline Clethraceae & Clethra scabra & generalists & 0.25 & non-vertebrate & 2 & 2 \\
\hline Ebenaceae & Diospyros inconstans & generalists & 421.9 & vertebrate & 0 & 2 \\
\hline Ericaceae & Gaylussacia brasiliensis & generalists & no data & vertebrate & 0 & 7 \\
\hline Erythroxylaceae & Erythroxylum deciduum & generalists & 100 & vertebrate & 0 & 2 \\
\hline Euphorbiaceae & Alchornea glandulosa & generalists & 51.3 & vertebrate & 0 & 1 \\
\hline Euphorbiaceae & Alchornea sidifolia & specialists & 52 & vertebrate & 3 & 23 \\
\hline Euphorbiaceae & Alchornea triplinervia & generalists & 54.1 & vertebrate & 2 & 11 \\
\hline Euphorbiaceae & Croton floribundus & generalists & 40.2 & non-vertebrate & 47 & 89 \\
\hline Euphorbiaceae & Croton urucurana & generalists & 8.3 & non-vertebrate & 83 & 99 \\
\hline Euphorbiaceae & Pera glabrata & generalists & 19.6 & vertebrate & 2 & 3 \\
\hline Euphorbiaceae & Sapium glandulatum & generalists & 34 & vertebrate & 12 & 39 \\
\hline Euphorbiaceae & Sebastiana brasiliensis & generalists & 17.2 & non-vertebrate & 9 & 22 \\
\hline Fabaceae & Albizia procera & generalists & 36 & non-vertebrate & 3 & 0 \\
\hline Fabaceae & Anadenanthera colubrina & generalists & 142 & non-vertebrate & 8 & 10 \\
\hline Fabaceae & Anadenanthera peregrina & generalists & 116.3 & non-vertebrate & 3 & 0 \\
\hline Fabaceae & Andira fraxinifolia & generalists & 14285 & vertebrate & 4 & 1 \\
\hline Fabaceae & Bauhinia forficata & generalists & 206.5 & non-vertebrate & 31 & 40 \\
\hline Fabaceae & Libidibia ferrea & generalists & 120.5 & non-vertebrate & 0 & 2 \\
\hline Fabaceae & Copaifera langsdorffii & generalists & 581.4 & vertebrate & 0 & 2 \\
\hline Fabaceae & Dalbergia brasiliensis & specialists & 43.5 & non-vertebrate & 5 & 3 \\
\hline Fabaceae & Dalbergia frutescens & generalists & 162.7 & non-vertebrate & 0 & 5 \\
\hline Fabaceae & Endlicheria paniculata & generalists & 1298.7 & vertebrate & 0 & 1 \\
\hline Fabaceae & Enterolobium contortisiliquum & generalists & 253 & vertebrate & 18 & 4 \\
\hline Fabaceae & Erythrina crista-galli & generalists & 372.8 & non-vertebrate & 3 & 2 \\
\hline Fabaceae & Erythrina falcata & generalists & 166.6 & vertebrate & 3 & 0 \\
\hline Fabaceae & Erythrina speciosa & specialists & 175.4 & non-vertebrate & 4 & 2 \\
\hline Fabaceae & Hymenaea courbaril & generalists & 3678 & vertebrate & 0 & 4 \\
\hline Fabaceae & Inga edulis & generalists & 539 & vertebrate & 5 & 1 \\
\hline Fabaceae & Inga laurina & generalists & 200 & vertebrate & 9 & 19 \\
\hline Fabaceae & Inga sessilis & specialists & 1030 & vertebrate & 10 & 7 \\
\hline Fabaceae & Leucochloron incuriale & specialists & 12.7 & non-vertebrate & 0 & 2 \\
\hline Fabaceae & Lonchocarpus cultratus & generalists & no data & non-vertebrate & 1 & 14 \\
\hline Fabaceae & Dahlstedtia muehlbergiana & generalists & 943.4 & non-vertebrate & 0 & 35 \\
\hline Fabaceae & Machaerium brasiliense & generalists & 137 & non-vertebrate & 1 & 0 \\
\hline Fabaceae & Machaerium hirtum & generalists & 250 & non-vertebrate & 0 & 1 \\
\hline Fabaceae & Machaerium nyctitans & generalists & 192.3 & non-vertebrate & 57 & 50 \\
\hline Fabaceae & Machaerium stipitatum & generalists & 158.7 & non-vertebrate & 16 & 35 \\
\hline Fabaceae & Machaerium villosum & generalists & 476.2 & non-vertebrate & 6 & 4 \\
\hline Fabaceae & Mangifera indica & generalists & 16466 & vertebrate & 0 & 1 \\
\hline Fabaceae & Mimosa bimucronata & generalists & 9.5 & non-vertebrate & 18 & 37 \\
\hline Fabaceae & Mimosa scabrella & specialists & 9.8 & non-vertebrate & 0 & 2 \\
\hline Fabaceae & Myroxylon peruiferum & generalists & 285 & non-vertebrate & 0 & 2 \\
\hline Fabaceae & Ormosia arborea & generalists & 1250 & vertebrate & 0 & 1 \\
\hline Fabaceae & Peltophorum dubium & generalists & 197.4 & non-vertebrate & 3 & 18 \\
\hline Fabaceae & Piptadenia gonoacantha & generalists & 42.3 & non-vertebrate & 3 & 1 \\
\hline Fabaceae & Platycyamus regnellii & generalists & 555.6 & non-vertebrate & 0 & 1 \\
\hline Fabaceae & Poecilanthe parviflora & specialists & 588.23 & non-vertebrate & 0 & 2 \\
\hline Fabaceae & Schizolobium parahyba & specialists & 954.4 & non-vertebrate & 2 & 0 \\
\hline Fabaceae & Senegalia polyphylla & generalists & 104.2 & non-vertebrate & 14 & 14 \\
\hline Fabaceae & Senna multijuga & generalists & 7.1 & non-vertebrate & 3 & 8 \\
\hline Lamiaceae & Aegiphila integrifolia & generalists & 3 & vertebrate & 4 & 3 \\
\hline Lauraceae & Nectandra grandiflora & specialists & 769.2 & vertebrate & 1 & 3 \\
\hline Lauraceae & Nectandra lanceolata & specialists & 1020.4 & vertebrate & 6 & 28 \\
\hline Lauraceae & Nectandrao oppositifolia & specialists & 769.2 & vertebrate & 0 & 2 \\
\hline Lauraceae & Ocotea puberula & generalists & 333.3 & vertebrate & 1 & 0 \\
\hline Lecythidaceae & Cariniana estrellensis & generalists & 83.3 & non-vertebrate & 0 & 1 \\
\hline Loganiaceae & Strychnos brasiliensis & generalists & no data & vertebrate & 0 & 7 \\
\hline Lythraceae & Lafoensia glyptocarpa & generalists & 24.4 & non-vertebrate & 1 & 0 \\
\hline Lythraceae & Lafoensia pacari & generalists & 25.6 & non-vertebrate & 1 & 7 \\
\hline Magnoliaceae & Magnolia champaca & generalists & 198 & vertebrate & 0 & 1 \\
\hline Magnoliaceae & Magnolia ovata & generalists & 250 & vertebrate & 0 & 3 \\
\hline Malvaceae & Abutilon regnelli & generalists & no data & non-vertebrate & 0 & 3 \\
\hline Malvaceae & Apeiba tibourbou & generalists & 11 & vertebrate & 0 & 2 \\
\hline Malvaceae & Ceiba speciosa & generalists & 57.7 & non-vertebrate & 12 & 5 \\
\hline
\end{tabular}




\begin{tabular}{|c|c|c|c|c|c|c|}
\hline Família & Espécie & Habitat & mg./seed & $\begin{array}{l}\text { Dispersal } \\
\text { Syndrome }\end{array}$ & N. DBH $\geq 5$ & N. DBH $<5$ \\
\hline Malvaceae & Guazuma ulmifolia & generalists & 47 & vertebrate & 23 & 16 \\
\hline Malvaceae & Heliocarpus popayanensis & generalists & 163 & non-vertebrate & 3 & 2 \\
\hline Malvaceae & Luehea divaricata & generalists & 3.8 & non-vertebrate & 17 & 23 \\
\hline Malvaceae & Pseudobombax grandiflorum & specialists & 54.2 & non-vertebrate & 4 & 2 \\
\hline Melastomataceae & Miconia latecrenata & generalists & no data & vertebrate & 2 & 45 \\
\hline Melastomataceae & Miconia pusilliflora & specialists & no data & vertebrate & 0 & 13 \\
\hline Melastomataceae & Miconia sellowiana & generalists & no data & vertebrate & 5 & 18 \\
\hline Melastomataceae & Pleroma heteromalla & generalists & no data & non-vertebrate & 0 & 26 \\
\hline Melastomataceae & Pleroma mutabilis & specialists & 0.3 & non-vertebrate & 1 & 8 \\
\hline Melastomataceae & Pleroma stenocarpa & generalists & no data & non-vertebrate & 2 & 3 \\
\hline Meliaceae & Cabralea canjerana & specialists & 980 & vertebrate & 1 & 8 \\
\hline Meliaceae & Cedrela fissilis & generalists & 47.6 & non-vertebrate & 4 & 6 \\
\hline Meliaceae & Guarea guidonia & generalists & 127 & vertebrate & 0 & 1 \\
\hline Meliaceae & Guarea macrophylla & generalists & 127 & vertebrate & 0 & 2 \\
\hline Meliaceae & Melia azedarach & generalists & 401 & vertebrate & 0 & 4 \\
\hline Meliaceae & Trichilia pallida & generalists & 43 & vertebrate & 0 & 1 \\
\hline Moraceae & Ficus adhatodifolia & generalists & no data & vertebrate & 0 & 1 \\
\hline Moraceae & Ficus luschnathiana & specialists & 0.2 & vertebrate & 3 & 1 \\
\hline Moraceae & Maclura tinctoria & generalists & 2.604 & vertebrate & 2 & 4 \\
\hline Moraceae & Morus nigra & generalists & 4.2 & vertebrate & 3 & 3 \\
\hline Moraceae & Sorocea bonplandii & generalists & 416.7 & vertebrate & 0 & 1 \\
\hline Myrsinaceae & Myrsine coriacea & generalists & 20.2 & vertebrate & 39 & 194 \\
\hline Myrsinaceae & Myrsine gardneriana & generalists & no data & vertebrate & 0 & 11 \\
\hline Myrsinaceae & Myrsine umbellata & generalists & 66.6 & vertebrate & 21 & 232 \\
\hline Myrtaceae & Campomanesia xanthocarpa & generalists & 76.9 & vertebrate & 1 & 0 \\
\hline Myrtaceae & Eugenia pyriformis & generalists & 854.7 & vertebrate & 0 & 10 \\
\hline Myrtaceae & Eugenia uniflora & generalists & 258.3 & vertebrate & 0 & 12 \\
\hline Myrtaceae & Myrcia hebepetala & specialists & 150 & vertebrate & 2 & 2 \\
\hline Myrtaceae & Myrcia splendens & generalists & 173 & vertebrate & 0 & 29 \\
\hline Myrtaceae & Psidium cattleianum & generalists & 15.38 & vertebrate & 0 & 43 \\
\hline Myrtaceae & Psidium guajava & specialists & 9 & vertebrate & 6 & 62 \\
\hline Myrtaceae & Psidium guineense & generalists & 53.1 & vertebrate & 0 & 2 \\
\hline Phytolaccaceae & Gallesia integrifolia & generalists & 65.8 & non-vertebrate & 0 & 1 \\
\hline Polygonaceae & Triplaris americana & generalists & no data & non-vertebrate & 3 & 10 \\
\hline Rhamnaceae & Hovenia dulcis & generalists & 25.6 & vertebrate & 0 & 1 \\
\hline Rosaceae & Eriobotrya japonica & generalists & 1447 & vertebrate & 0 & 18 \\
\hline Rosaceae & Prunus myrtifolia & generalists & no data & vertebrate & 0 & 14 \\
\hline Rubiaceae & Coutarea hexandra & generalists & 4 & non-vertebrate & 0 & 1 \\
\hline Rubiaceae & Psychotria vellosiana & specialists & no data & vertebrate & 0 & 1 \\
\hline Rubiaceae & Psychotria nuda & specialists & 497 & vertebrate & 0 & 9 \\
\hline Rubiaceae & Psychotria vellosiana & generalists & 6 & vertebrate & 0 & 1 \\
\hline Rutaceae & Balfourodendron riedelianum & generalists & 406.5 & non-vertebrate & 1 & 3 \\
\hline Rutaceae & Esenbeckia febrifuga & generalists & 35.7 & non-vertebrate & 0 & 6 \\
\hline Rutaceae & Zanthoxylum rhoifolium & generalists & 12 & vertebrate & 4 & 10 \\
\hline Rutaceae & Zanthoxylum riedelianum & generalists & 25 & vertebrate & 0 & 3 \\
\hline Salicaceae & Casearia lasiophylla & generalists & 50 & vertebrate & 4 & 18 \\
\hline Salicaceae & Casearia sylvestris & generalists & 3 & vertebrate & 17 & 126 \\
\hline Salicaceae & Xylosma ciliatifolia & generalists & 6.7 & vertebrate & 0 & 3 \\
\hline Salicaceae & Xylosma pseudosalzmanii & generalists & no data & vertebrate & 0 & 2 \\
\hline Sapindaceae & Allophylus edulis & generalists & 33.5 & vertebrate & 0 & 6 \\
\hline Sapindaceae & Cupania vernalis & generalists & 387.6 & vertebrate & 0 & 24 \\
\hline Sapindaceae & Matayba elaeagnoides & generalists & 307.7 & vertebrate & 0 & 4 \\
\hline Sapindaceae & Matayba juglandifolia & generalists & no data & vertebrate & 0 & 1 \\
\hline Sapindaceae & Sapindus saponaria & generalists & 767 & vertebrate & 1 & 0 \\
\hline Sapotaceae & Chrysophyllum gonocarpum & generalists & 5670 & vertebrate & 3 & 0 \\
\hline Sapotaceae & Siparuna guianensis & generalists & 20 & vertebrate & 0 & 9 \\
\hline Solanaceae & Cestrum corymbosum & specialists & no data & vertebrate & 1 & 24 \\
\hline Solanaceae & Cestrum intermedium & specialists & no data & vertebrate & 2 & 8 \\
\hline Solanaceae & Solanum swartzianum & generalists & no data & vertebrate & 3 & 10 \\
\hline Solanaceae & Solanum campaniforme & generalists & 1.3 & vertebrate & 0 & 3 \\
\hline Solanaceae & Solanum lycocarpum & generalists & 15.2 & vertebrate & 1 & 0 \\
\hline Solanaceae & Solanum mauritianum & generalists & 1.1 & vertebrate & 26 & 40 \\
\hline Solanaceae & Solanum pseudoquina & generalists & 76.9 & vertebrate & 0 & 3 \\
\hline Solanaceae & Solanum variabile & generalists & 10 & vertebrate & 0 & 144 \\
\hline Urticaceae & Boehmeria caudata & specialists & 0.1 & non-vertebrate & 5 & 22 \\
\hline Urticaceae & Cecropia hololeuca & specialists & 1.1 & vertebrate & 23 & 48 \\
\hline Urticaceae & Cecropia pachystachya & generalists & 0.9 & vertebrate & 5 & 1 \\
\hline Verbenaceae & Aloysia virgata & generalists & 0.2 & vertebrate & 1 & 5 \\
\hline
\end{tabular}




\begin{tabular}{|c|c|c|c|c|c|c|}
\hline Família & Espécie & Habitat & mg./seed & $\begin{array}{c}\text { Dispersal } \\
\text { Syndrome }\end{array}$ & N. DBH $\geq 5$ & N. $\mathrm{DBH}<5$ \\
\hline Verbenaceae & Citharexylum myrianthum & specialists & 52.6 & vertebrate & 79 & 24 \\
\hline
\end{tabular}

686 GBIF; Global Biodiversity Information Facility; http://www.gbif.org (accessed on $1^{\text {st }}$ Mar 2018)

687 SID; Kew Royal Botanic Gardens; Seed Information Database; http://data.kew.org/sid/ (accessed on $1^{\text {st }}$ Mar 2018)

688 Lorenzi, H., 1992. Árvores brasileiras: manual de identificação e cultivo de plantas arbóreas nativas do Brasil. Nova 689 Odessa, Brazil: Instituto Plantarum de Estudos da Flora 352p.

690 Lorenzi, H., 1998. Árvores Brasileiras: manual de identificação e cultivo de plantas arbóreas nativas do Brasil. vol.

691 2. Nova Odessa, Brazil: Instituto Plantarum de Estudos da Flora 352p.

692

693

694 Figures

6951.
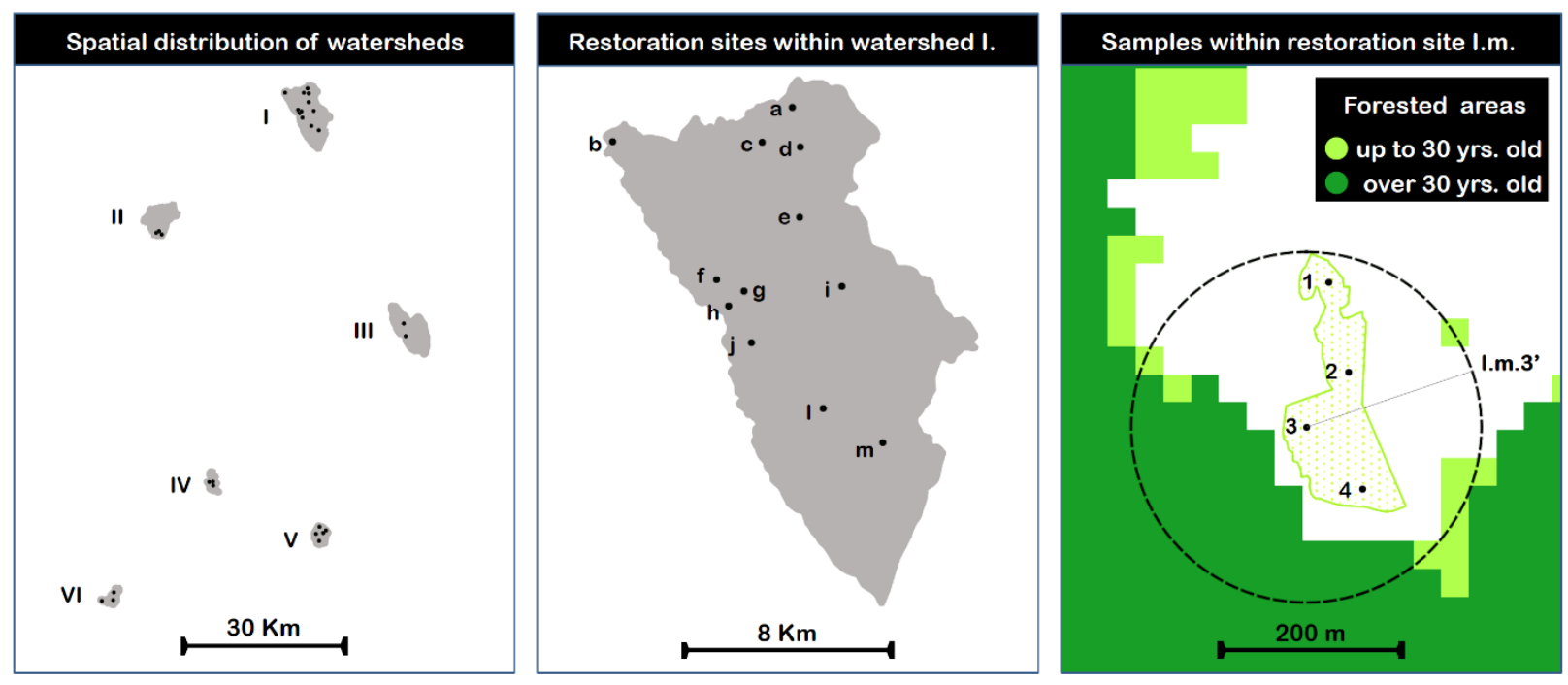
(a) stem density

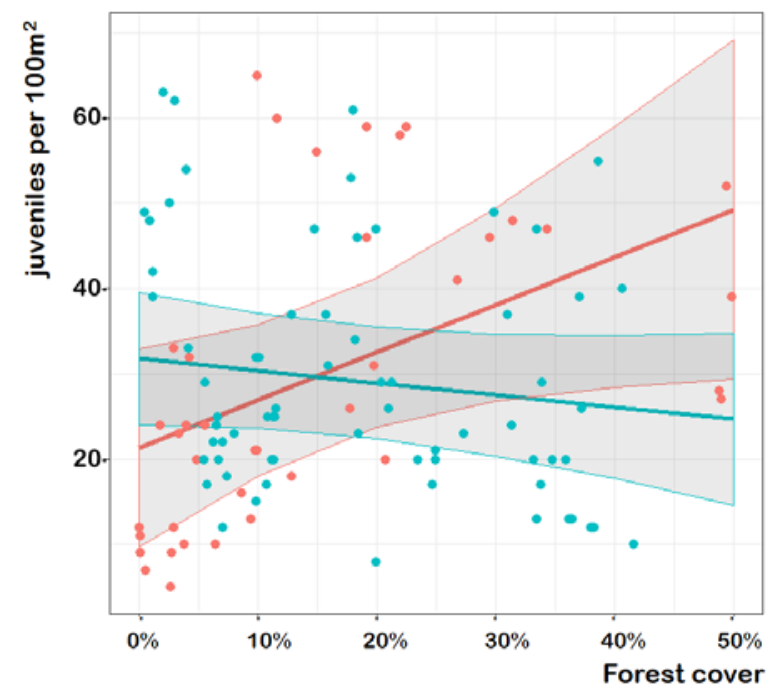

(c) vertebrate-dispersed density

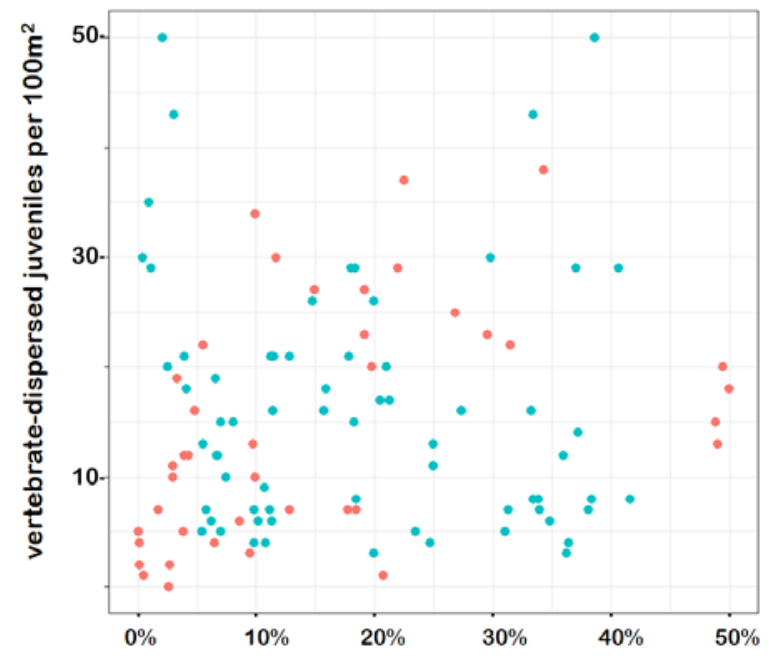

Forest cover

708

709

710

711

712

713

714

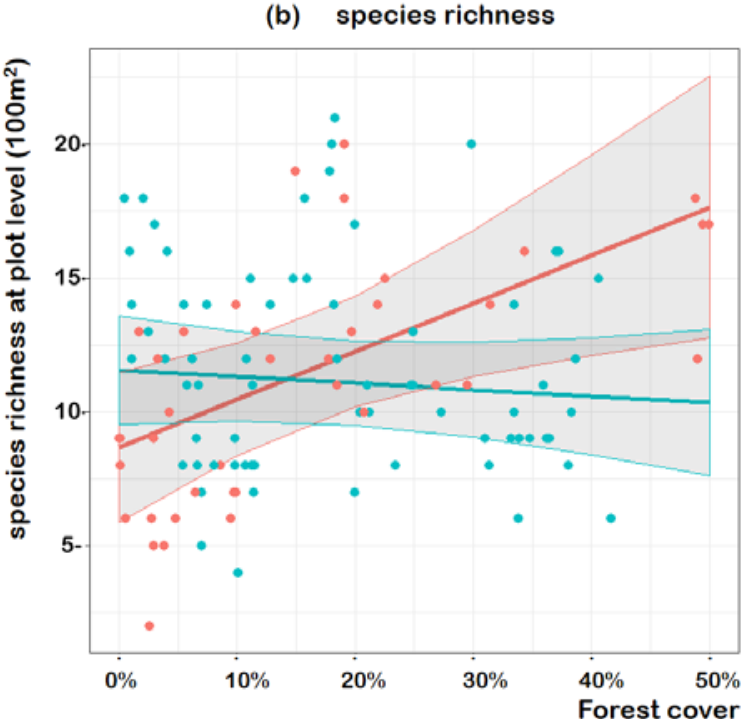

(d) non vertebrate-dispersed density

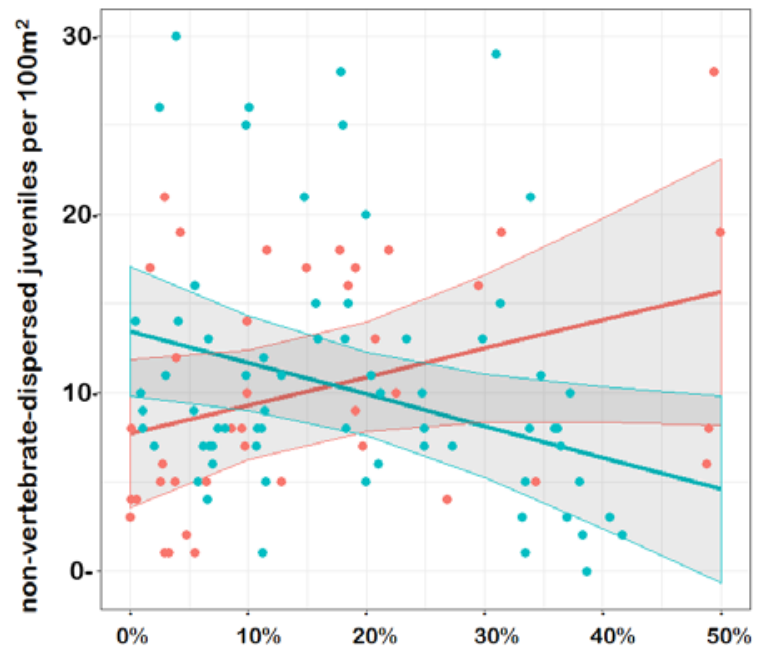

Forest cover

Old forest cover ( $\geq 30$ years) 
(a) Seed-mass community-weighted mean

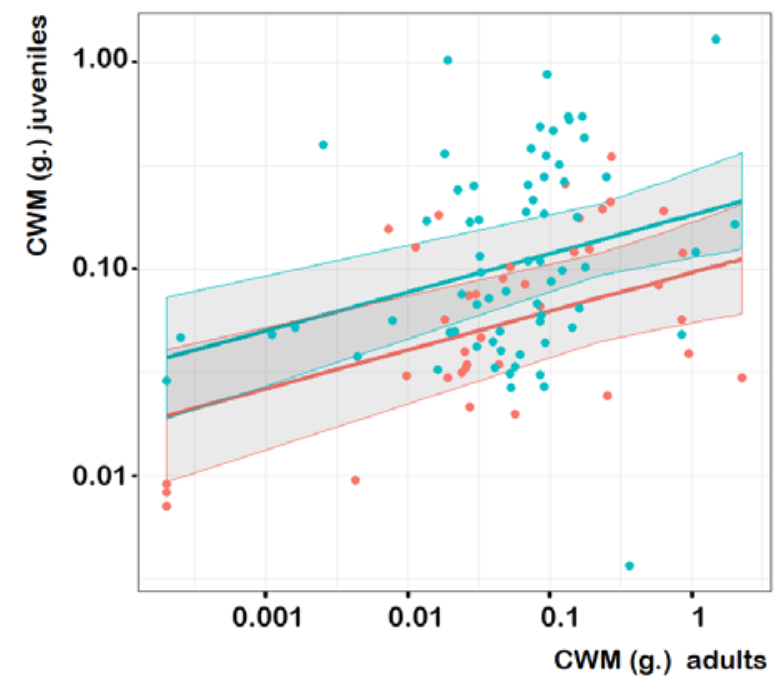

717 (b) Relative abundance of forest specialists

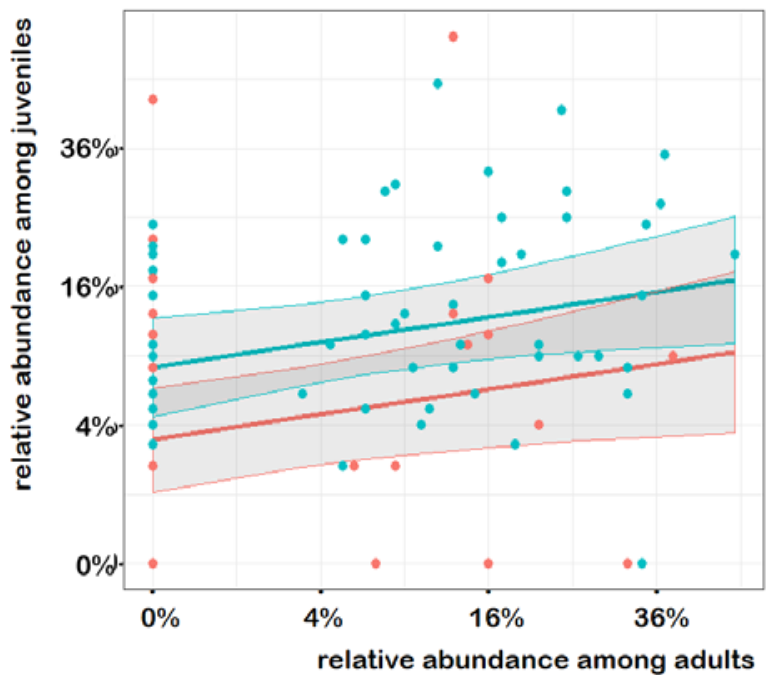

- Old forest cover ( $\geq \mathbf{3 0}$ years) 